\title{
Increasing nitrogen supply to phosphorus-deficient Medicago sativa decreases shoot growth and enhances root exudation of tartrate to discharge surplus carbon dependent on nitrogen form
}

Honghua He ( $\nabla$ honghuahe@ms.iswc.ac.cn )

Institute of Soil and Water Conservation, Northwest A\&F University https://orcid.org/0000-0002-5785-

2242

Zekun Zhang

Northwest A\&F University

Qi Peng

Chinese Academy of Sciences and Ministry of Water Resources, Yangling, Shaanxi 712100, China Chao Chang

Northwest A\&F University

Rui Su

Northwest A\&F University

Xiao Cheng

Northwest A\&F University

Yingxin Li

Chinese Academy of Sciences and Ministry of Water Resources, Yangling, Shaanxi 712100, China

Jiayin Pang

The University of Western Australia

Sheng Du

Northwest A\&F University

Hans Lambers

The University of Western Australia

\section{Research Article}

Keywords: Carboxylate release, Medicago sativa, nitrogen form, nitrogen to phosphorus ratio, surplus carbon, tartrate

Posted Date: June 28th, 2021

DOl: https://doi.org/10.21203/rs.3.rs-636655/v1 
License: (c) (i) This work is licensed under a Creative Commons Attribution 4.0 International License. Read Full License

Version of Record: A version of this preprint was published at Plant and Soil on September 24th, 2021. See the published version at https://doi.org/10.1007/s11104-021-05161-y. 


\section{Abstract}

\section{Aims}

Carboxylate release by roots has been considered a strategy for mobilization and acquisition of phosphorus $(P)$. However, recently, it was argued that carboxylate release may be a way to discharge surplus carbon produced under conditions that limit plant growth. Plant $P$ status may not be the main factor driving carboxylate release by roots. Instead, plant nitrogen $(\mathrm{N})$ status and/or N:P ratio of the soil or plant may play a more important role in enhancing carboxylate release.

\section{Methods}

A greenhouse pot experiment was performed to grow alfalfa in a P-deficient soil, supplied with two rates of $P\left(0\right.$ and $\left.20 \mathrm{mg} \mathrm{kg}^{-1}\right)$ in combination with four forms of nitrogen $(N)$ at five rates $(0,25,50,75$, and $100 \mathrm{mg} \mathrm{kg}^{-1}$ ), to explore the effects of $\mathrm{P}$ rate, $\mathrm{N}$ form, $\mathrm{N}$ rate, and their interactions on plant growth, $\mathrm{P}$ and $\mathrm{N}$ status, and carboxylate release, and to determine the factors driving carboxylate release.

\section{Results}

Nitrogen addition weakened the positive effect of $\mathrm{P}$ addition on plant growth, and increased plant $\mathrm{N}$ ([N]) and $\mathrm{P}$ concentrations ([P]); $\mathrm{P}$ addition increased plant $[\mathrm{P}]$, but weakened the effect of $\mathrm{N}$ addition on plant [N]. The amount of tartrate increased dramatically with increasing $\mathrm{N}$ rate, which decreased shoot growth, depending on $\mathrm{N}$ form. At high $\mathrm{P}$ supply, tartrate exudation correlated negatively with shoot biomass.

\section{Conclusions}

Nitrogen addition to P-deficient alfalfa decreased shoot growth and enhanced the release of tartrate, likely to discharge surplus carbon; and the effects varied with $\mathrm{N}$ form.

\section{Introduction}

Phosphorus $(\mathrm{P})$ is an essential plant macronutrient and plays important roles in plant growth and metabolism. Plant growth is often limited by $\mathrm{P}$ deficiency, because inorganic phosphate $(\mathrm{Pi})$ is often strongly sorbed to soil particles and the bioavailability of $\mathrm{P}$ is low in many soils (Lambers and Plaxton 2015). Many species, including Lupinus (lupin) (Lambers et al. 2013) and Proteaceae species (Lambers et al. 2011), increase their carboxylate release from roots when growing under P-limited conditions, and the release of carboxylates is controlled systemically by shoot or leaf $\mathrm{P}$ concentration ([P]) (Shane et al. 2008; Shen et al. 2003). The released carboxylates, especially citrate and malate, mobilize sparinglysoluble soil $\mathrm{P}$ by competing with both inorganic and organic $\mathrm{P}$ for binding sites in rhizosphere soil, thus 
making P more available for uptake by plants (Lambers et al. 2011). However, release of carboxylates is affected by a number of factors; their contribution to $\mathrm{P}$ mobilization and acquisition can vary greatly and may not be as usually expected (Wang and Lambers 2020).

Low $\mathrm{P}$ availability in soil does not always stimulate release of carboxylates by roots (Abrahão et al. 2018; He et al. 2017b; Suriyagoda et al. 2012), and some studies have shown that the amounts of carboxylates released may even decrease with decreasing soil P supply (Huang et al. 2017; Wen et al. 2020). There are also studies showing that carboxylate release does not relate consistently to a plant's P-acquisition capacity (Pandey et al. 2014; Pearse et al. 2007; Ryan et al. 2014). Even when there are significant correlations between rhizosphere water-soluble $\mathrm{P}$ and rhizosphere carboxylates, the correlation coefficients are very low, and rhizosphere carboxylates may play minor roles in improving P availability and uptake (Wang et al. 2016). As release of carboxylates is often restricted to certain parts of the roots, e.g., root apices, the amount of $P$ mobilized by carboxylates may be limited and insufficient to enhance plant growth (Ryan et al. 2014). Furthermore, the potential of carboxylates to mobilize $P$ may be weakened rapidly after they are released by roots, due to their sorption onto soil particles (Oburger et al. 2011) and degradation by soil microorganisms (Weisskopf et al. 2006). Therefore, a greater release of carboxylates does not necessarily result in greater plant biomass and crop yield (Pandey et al. 2014; Ryan et al. 2014).

Recently, Prescott et al. (2020) put forward a 'surplus carbon (C)' hypothesis. In this paper, the authors showed evidences of plants having surplus fixed $C$ under conditions such as insufficient nutrients (including P and/or nitrogen (N)) (Augusto et al. 2017; Harpole et al. 2011) or water (McDowell 2011; Muller et al. 2011; Sharma et al. 2021), low temperature (Hoch and Körner 2009; Karst et al. 2017), or elevated atmospheric $\mathrm{CO}_{2}$ (Jiang et al. 2020; Körner 2015), when plant growth declines but photosynthesis continues (although often at a slower rate) under these conditions. When aboveground growth is limited by $\mathrm{N}$ or $\mathrm{P}$ (or some other nutrient), some of the surplus $\mathrm{C}$ is transported from leaves to roots and further metabolized there, and thereafter may be either stored in roots or released as carboxylates, amino acids, sugars, or otherwise (Carvalhais et al. 2011; van Dam and Bouwmeester 2016). Surplus C may contain nonstructural carbohydrates (NSCs) and other C-rich metabolites, and the composition depends on whether $\mathrm{N}$ or $\mathrm{P}$ is the most limiting nutrient (Prescott et al. 2020). Continuous storage of NSCs under nutrient shortage promotes root growth and result in greater root mass ratios (Hermans et al. 2006; Litton et al. 2007). Prescott et al. argued that disposal of surplus C may be a way to alleviate the oversupply of resources that plants have in surplus to their requirements. Therefore, when explaining plant-soil interactions, the production and disposal of surplus $\mathrm{C}$ under growth-limiting conditions should be considered before thinking of adaptive strategies, investments or trade-offs (Prescott et al. 2020).

In a previous study by He et al. (2020), when an alkaline low-P and low-N soil was used to grow alfalfa (Medicago sativa), supplied with different rates of $\mathrm{P}\left(0,5\right.$, and $\left.20 \mathrm{mg} \mathrm{kg}^{-1}\right)$ and $\mathrm{N}\left(50\right.$ and $\left.100 \mathrm{mg} \mathrm{kg}^{-1}\right)$, roots released a large amount of carboxylates, among which tartrate was the most abundant and its amount decreased with increasing P supply, but increased with increasing N supply, while the amount of 
other carboxylates that are more commonly reported, including citrate and malate, were much smaller and did not always vary considerably with the rates of either $\mathrm{P}$ or $\mathrm{N}$ supply. The above-mentioned results of the study of He et al. (2020), together with the 'surplus C' hypothesis put forward by Prescott et al. (2020), led us to consider that plant P status may not be the main factor driving the release of tartrate from alfalfa roots; instead, $\mathrm{N}$ status and/or N:P ratio of the soil or plant may play a more important role in enhancing tartrate release, which may be a way to discharge surplus $C$ produced in plants when $N$ is oversupplied under $\mathrm{P}$ shortage, rather than to increase $\mathrm{P}$ acquisition. In addition to the rates of $\mathrm{P}$ and $\mathrm{N}$ supply, $\mathrm{N}$ form may also affect root morphology and/or physiology, thus impacting plant $\mathrm{P}$ and $\mathrm{N}$ status (Ngwene et al. 2010; Niu et al. 2013; Wang et al. 2011).

In the present study, a pot experiment was carried out to grow alfalfa in a P-deficient loess soil with different rates of added $\mathrm{P}$ and $\mathrm{N}$ in different forms to explore the effects of $\mathrm{P}$ rate, $\mathrm{N}$ rate, $\mathrm{N}$ form, and their interactions on plant growth, $\mathrm{P}$ and $\mathrm{N}$ status, and release of carboxylates, and to investigate which factor is more important in driving the release of carboxylates (mainly tartrate), and to determine the nature of the interactions between and/or among factors. The following hypotheses were tested: (i) plant growth would be enhanced by $\mathrm{P}$ addition as well as $\mathrm{N}$ addition, and belowground biomass allocation would decrease with increasing $P$ rate, and also with increasing $N$ rate; (ii) plant $P$ concentration ([P]) and $N$ concentration ( $[N])$ would increase with increasing $P$ rate, and also with increasing $N$ rate, while $N: P$ ratio would increase with increasing $\mathrm{N}$ rate but decline with increasing $\mathrm{P}$ rate; (iii) the amount of tartrate released by roots would decline with increasing $P$ rate but increase with increasing $N$ rate, and it would have a closer relationship with plant [N] than with plant [P]; and (iv) the effects of $\mathrm{N}$ rate on the abovementioned parameters would depend on the forms of the added $\mathrm{N}$.

\section{Materials And Methods}

Experimental design and plant cultivation

A loess soil was collected from the top 40-cm layer of an undisturbed site $\left(34^{\circ} 51^{\prime} 30^{\prime \prime} \mathrm{N}, 109^{\circ} 19^{\prime} 23^{\prime \prime} \mathrm{E}\right)$ in a hilly-gully region at Ansai County, Shaanxi Province on the Chinese Loess Plateau, and used as the substrate for pot experiment in the present study. The $\mathrm{pH}$ of the soil was 8.7 , and the field capacity was $33 \%$. The concentrations of total $\mathrm{N}$, total $\mathrm{P}$, and bicarbonate-extractable $\mathrm{P}$ in the soil were $96 \mathrm{mg} \mathrm{kg}^{-1}, 493$ $\mathrm{mg} \mathrm{kg}^{-1}$, and $3.3 \mathrm{mg} \mathrm{kg}^{-1}$, respectively; the concentrations of total potassium $(\mathrm{K})$ and organic $\mathrm{C}$ were 1.5 $\mathrm{mg} \mathrm{g}^{-1}$ and $1.6 \mathrm{mg} \mathrm{g}^{-1}$, respectively. The soil was air-dried and screened through a 2-mm sieve before filling the pots. For each plastic pot (of $12 \mathrm{~cm}$ inner diameter and $15 \mathrm{~cm}$ height), a plastic bag was lined inside first, then $2.0 \mathrm{~kg}$ of the air-dried and sieved soil was filled into the bag; a total of 136 pots were filled in this way. Potassium was added at $50 \mathrm{mg} \mathrm{kg}^{-1}$ soil as potassium chloride $(\mathrm{KCl})$ aqueous solution to the soil in all pots.

For 68 out of the 136 pots, no $P$ was added to the soil (hereafter referred to as $0 \mathrm{P}$ ), while for another 68 pots, $\mathrm{P}$ was added at $20 \mathrm{mg} \mathrm{P} \mathrm{kg}^{-1}$ soil (hereafter referred to as 20P) as a monopotassium phosphate $\left(\mathrm{KH}_{2} \mathrm{PO}_{4}\right)$ aqueous solution. Then four forms of $\mathrm{N}$, i.e. calcium nitrate $\left(\mathrm{Ca}\left(\mathrm{NO}_{3}\right)_{2}\right)$, ammonium nitrate 
$\left(\mathrm{NH}_{4} \mathrm{NO}_{3}\right)$, ammonium sulfate $\left(\left(\mathrm{NH}_{4}\right)_{2} \mathrm{SO}_{4}\right)$, or urea $\left(\mathrm{CO}\left(\mathrm{NH}_{2}\right)_{2}\right)$, were added to the soil at different rates. For both $\mathrm{OP}$ and $20 \mathrm{P}$, no $\mathrm{N}$ was added (hereafter referred to as $\mathrm{ON}$ ) to the soil in four out of the 68 pots, and the four pots without added $\mathrm{P}$ and N (OPON) were treated as the control; for the rest of the 64 pots, $\mathrm{N}$ was added at four rates, i.e. $25,50,75$, and $100 \mathrm{mg} \mathrm{N} \mathrm{kg}^{-1}$ soil (hereafter referred to as $25 \mathrm{~N}, 50 \mathrm{~N}, 75 \mathrm{~N}$, and $100 \mathrm{~N}$, respectively) as an aqueous solution of $\mathrm{Ca}\left(\mathrm{NO}_{3}\right)_{2}, \mathrm{NH}_{4} \mathrm{NO}_{3},\left(\mathrm{NH}_{4}\right)_{2} \mathrm{SO}_{4}$, or $\mathrm{CO}\left(\mathrm{NH}_{2}\right)_{2}$. There were four replicates for each $\mathrm{N}$ rate of each $\mathrm{N}$ form. After addition of the aqueous solution of $\mathrm{K}, \mathrm{P}$, and $\mathrm{N}$, the soil in each pot was watered to $60 \%$ of the field capacity, then incubated for two weeks in a greenhouse at the Institute of Soil and Water Conservation (34 $\left.{ }^{\circ} 16^{\prime} 19^{\prime \prime} \mathrm{N}, 108^{\circ} 04^{\prime} 20^{\prime \prime} \mathrm{E}\right)$, Yangling, China. In order to obtain a substrate with homogenous distribution of the added K, P, and N, after incubation, the soil in each pot was air dried and screened through a 2-mm sieve once again separately, then mixed thoroughly and filled back to the pot that was lined with a plastic bag inside.

In the middle of September 2019, seeds of alfalfa (Medicago sativa L. cv Golden Empress) were surface sterilized by soaking the seeds in $10 \%$ (v:v) hydrogen peroxide $\left(\mathrm{H}_{2} \mathrm{O}_{2}\right)$ for $10 \mathrm{~min}$, then rinsed with deionized (DI) water three times and placed on moist filter paper in Petri dishes to germinate overnight (He et al. 2017b). Sixty seeds were sown in each pot at $0.5 \mathrm{~cm}$ depth, and the seedlings were thinned to 50 per pot two weeks after sowing. Soil water content was maintained at $60 \%$ of field capacity by weighing the pots and replenishing DI water every three days during the experiment, and no drainage was allowed. Plants were cultivated for a total of 100 days before being harvested in late December, 2019.

Collection of rhizosheath carboxylates and measurement of plant biomass

When plants were harvested at 100 days after sowing, the aboveground parts (hereafter referred to as shoots) of the plants in each pot were severed at the soil surface. The belowground parts (hereafter referred to as roots) of the plants and the soil in each pot were taken out of the pot together with the plastic bag; the roots were gently separated from the bulk soil, and the soil that was still attached to the roots after gently shaking was defined as rhizosheath soil (Pang et al. 2017). For each pot, rhizosheath carboxylates were extracted by soaking and gently stirring about $1.0 \mathrm{~g}$ fresh fine roots and rhizosheath soil in $20 \mathrm{~mL}$ of $0.2 \mathrm{mM} \mathrm{CaCl}_{2}$ in a glass beaker for $5 \mathrm{~min}$. About $1 \mathrm{~mL}$ subsample of the extract was taken and filtered into a 1-mL HPLC vial through a $0.22-\mu \mathrm{m}$ syringe filter; then a drop of concentrated phosphoric acid $\left(\mathrm{H}_{3} \mathrm{PO}_{4}\right)$ was added to the vial to acidify the extract and prevent microbial degradation of the carboxylates. All extracts were stored at $-20^{\circ} \mathrm{C}$ until analysis (He et al. 2020).

The roots were soaked, collected and thoroughly washed with tap water to remove the rhizosheath soil as much as possible, then rinsed with DI water and oven-dried at $60^{\circ} \mathrm{C}$ for $48 \mathrm{~h}$ to obtain the dry mass. The roots that were not soaked were treated the same as those that were soaked, but weighed separately to obtain the dry mass. Total root dry mass (RDM) in each pot was calculated as the sum of the dry mass of the roots soaked and those not soaked. Shoots were also oven dried at $60^{\circ} \mathrm{C}$ for $48 \mathrm{~h}$ and weighed to obtain shoot dry mass (SDM). Root mass ratio (RMR) was calculated as the ratio between RDM to the sum of RDM and SDM. 
Determination of plant $\mathrm{N}$ and $\mathrm{P}$ concentrations, and calculation of plant $\mathrm{N}: \mathrm{P}$ ratios

Concentrations of $N([N])$ and $P([P])$ in shoots and roots were determined. Each oven-dried sample was finely ground using a stainless pulverizer, about $0.1 \mathrm{~g}$ subsample of each ground sample was weighed and digested in a hot sulfuric acid $\left(\mathrm{H}_{2} \mathrm{SO}_{4}\right)-\mathrm{H}_{2} \mathrm{O}_{2}$ mixture. The concentration of $\mathrm{N}$ in the digestion solution was determined using a Kjeltec 2300 Automatic Kjeldahl Apparatus (Foss, Höganäs, Sweden) (Baker and Thompson 1992), and the concentration of $P$ in the digestion solution was determined using the vanadium molybdenum yellow colorimetric method (Gupta et al. 1993). The N:P ratios in shoots and roots were calculated as the mass ratios of $\mathrm{N}$ to $\mathrm{P}$, based on the determined $[\mathrm{N}]$ and $[\mathrm{P}]$ in shoots and roots, respectively.

Analysis of rhizosheath carboxylates

Carboxylates in the rhizosheath extracts of $0 \mathrm{~N}, 25 \mathrm{~N}$, and $100 \mathrm{~N}$ at both $0 \mathrm{P}$ and $20 \mathrm{P}$ were analyzed using High Performance Liquid Chromatography (HPLC). The apparatus used included a Waters E2695 HPLC, a Waters 2998 detector, and a Waters Symmetry C18 reverse phase column (Waters, Milford MA, USA). Carboxylic acids including tartaric acid, malonic acid, citric acid, malic acid, succinic acid, and acetic acid were used as the standards. The mobile phase included $20 \mathrm{mM}$ monopotassium phosphate $\left(\mathrm{KH}_{2} \mathrm{PO}_{4}\right)$ and $100 \%$ methanol, the $\mathrm{KH}_{2} \mathrm{PO}_{4}$ solution was pre-adjusted to $\mathrm{pH} 2.5$ with concentrated $\mathrm{H}_{3} \mathrm{PO}_{4}$ and flowed at a rate of $0.6 \mathrm{~mL} \mathrm{~min}^{-1}$, and the methanol flowed at a rate of $0.01 \mathrm{~mL} \mathrm{~min}^{-1}$. Each sample was run for $13 \mathrm{~min}$, and carboxylates were detected at $210 \mathrm{~nm}$ (He et al. 2020). The amounts of carboxylates in the rhizosheath were expressed in mmol per unit dry mass of the roots used for extraction.

\section{Statistical analysis}

For the two $\mathrm{P}$ rates (i.e. $\mathrm{OP}$ and $2 \mathrm{OP}$ ), all four forms of $\mathrm{N}$ (i.e. $\mathrm{Ca}\left(\mathrm{NO}_{3}\right)_{2}, \mathrm{NH}_{4} \mathrm{NO}_{3},\left(\mathrm{NH}_{4}\right)_{2} \mathrm{SO}_{4}$, and $\mathrm{CO}\left(\mathrm{NH}_{2}\right)_{2}$ ), and all $\mathrm{N}$ rates except $0 \mathrm{~N}$ (i.e. $25 \mathrm{~N}, 50 \mathrm{~N}, 75 \mathrm{~N}$, and $100 \mathrm{~N}$ ), a three-way analysis of variance (ANOVA) was carried out to investigate the effects of $P$ rate $\left(P_{r}\right), N$ form $\left(N_{f}\right), N$ rate $\left(N_{r}\right)$, the interactions between any two of the three factors (i.e. $P_{r} \times N_{f}, P_{r} \times N_{r}$, and $N_{f} \times N_{r}$ ), and the interaction among the three factors (i.e. $P_{r} \times N_{f} \times N_{r}$ ) on parameters of plant biomass, $[N]$ and $[P], N: P$, and the amounts of rhizosheath carboxylates. The three-way ANOVA was carried out using the general linear model in the SPSS 25.0 software package (IBM, Montauk, New York, USA), and the effects were determined to be significant at $P$ $<0.05$. Because $\mathrm{ON}$ was shared by all four forms of $\mathrm{N}$, it was not included in the ANOVA. The criterion to determine the effect of a treatment to be significant if $P<0.05$ has been and still is widely used. However, it is getting increasingly challenged by statisticians, and presenting the effect size is encouraged when discussing the effect of a treatment (Goodman et al. 2019). Therefore, in addition to the effects determined based on the $P$-values of three-way ANOVA, the effect size of each treatment relative to the control (i.e. OPON) was calculated, and the interaction between $\mathrm{P}$ and $\mathrm{N}$ was determined for each treatment with added $\mathrm{P}$ and $\mathrm{N}$. Here, we presented both the $P$-values of three-way ANOVA and the effect sizes, but relied more on the effect sizes for description and discussion of the results, as low replication or statistical power in experiments may obscure the ability to detect biologically meaningful responses 
using the $P$-value criterion, while the effect sizes are the log response ratios representing the proportional response to experimental treatment and tend to be distributed normally (Harpole et al. 2011).

In this study, the effect sizes were calculated according to the method described by Harpole et al. (2011), but with some modifications. Briefly, the effect size of a treatment for a parameter was calculated as the log response ratio, i.e. the log value of the ratio between the value of the parameter in the treatment to that in the control. Therefore, the effect sizes of $\mathrm{P}$ and $\mathrm{N}$ were calculated as follows:

Effect size of 20P $=\operatorname{Ln}(20 \mathrm{PON} / 0 \mathrm{PON})$

Effect size of $x N=\operatorname{Ln}(0 P x N / O P O N)$

Then the simple addition of the effect sizes of $\mathrm{P}$ and $\mathrm{N}$ for each treatment with added $\mathrm{P}$ and $\mathrm{N}$ was calculated as:

Effect size of $(20 P+x N)=$ Effect size of $20 P+$ Effect size of $x N$

and the effect size of the interaction between $\mathrm{P}$ rate and $\mathrm{N}$ rate was calculated as:

Effect size of $(20 \mathrm{P} \times x N)=\operatorname{Ln}(20 \mathrm{PxN} / 0 \mathrm{P} 0 \mathrm{~N})$

where $x=25,50,75$, and 100 , respectively, and the effect size of each $N$ rate for each $N$ form was calculated separately. As the effect size of a treatment was 0.05 and -0.05 when the response ratio was 1.05 and 0.95 , respectively, an effect size $>0.05$ indicates that the value of a parameter increased by more than $5 \%$ compared with the control and the effect was positive, while an effect size $<-0.05$ indicates that the value of a parameter decreased by more than $5 \%$ compared with the control and the effect was negative; an effect size between -0.05 and 0.05 indicates that the effect was negligible. Furthermore, intuitively, the interaction was considered additive when the effect size of the interaction was equivalent (a less than $10 \%$ difference was considered equivalent) to that of the simple addition, while it was considered super-additive when the effect size of the interaction was at least $10 \%$ greater than that of the simple addition, and sub-additive when the effect size of the interaction was at least $10 \%$ less than that of the simple addition.

Bivariate Pearson correlations were used to determine the correlations between the mean amount of each rhizosheath carboxylate and mean shoot $[\mathrm{N}]$, root [N], shoot N:P, root N:P, SDM, RDM, and total plant biomass (the sum of SDM and RDM) in the control and each treatment under OP and 20P separately. The correlation analyses were performed using the SPSS 25.0 software package, and the correlations were considered significant at $P<0.05$.

\section{Results}

Plant biomass 
According to the results of three-way ANOVA, when $\mathrm{N}$ was added, increasing $\mathrm{P}$ supply significantly increased SDM, RDM, and RMR (all $P \leq 0.001$ ) (Fig. 1, Table 1). The form of $\mathrm{N}$ had a significant effect on $\operatorname{SDM}(P=0.032)$ and $\operatorname{RMR}(P<0.001)$ (Fig. 1a and $\mathrm{c})$, but not on RDM $(P>0.05$, Fig. 1 b). Among all four forms of $\mathrm{N}, \mathrm{Ca}\left(\mathrm{NO}_{3}\right)_{2}$ resulted in the smallest $\mathrm{SDM}$, while $\mathrm{NH}_{4} \mathrm{NO}_{3}$ resulted in the highest RMR. When $\mathrm{N}$ was added, mean SDM and RMR varied significantly with $\mathrm{N}$ rate $(P=0.008$ for SDM and $P=0.004$ for RMR, respectively), with SDM being the largest at $50 \mathrm{~N}$ and the smallest at $100 \mathrm{~N}$, while RMR declined with increasing $\mathrm{N}$ rate. There was a significant interaction between $\mathrm{P}$ rate and $\mathrm{N}$ rate on $\operatorname{RDM}(P<0.001)$, which was the largest at $50 \mathrm{~N}$ and the smallest at $100 \mathrm{~N}$ at $\mathrm{OP}$, but decreased with increasing $\mathrm{N}$ rate at $20 \mathrm{P}$. Based on the calculated effect sizes, the effect of $P$ was positive on both SDM and RDM, but negligible on RMR; the effect of $\mathrm{N}$ was positive on SDM in almost all treatments, but negative on RDM in most treatments and on RMR in almost all treatments. The interactive effects between P and N on SDM and RDM were always positive and sub-additive in most treatments, while that on RMR was negative and super-additive in most treatments. Adding $\mathrm{N}$ weakened the positive effect of $\mathrm{P}$ on SDM in most treatments and on RDM in all treatments at 20P, while adding $\mathrm{P}$ weakened the negative effect of $\mathrm{N}$ on RMR in most treatments.

Table 1

Statistical level of significances ( $P$-values) of the three-way analysis of variance (ANOVA) for various parameters. $P_{r}, N_{f}$, and $N_{r}$ represent phosphorus $(P)$ addition rate, nitrogen $(N)$ form, and $N$ addition rate, respectively. $[N]$ and $[P]$ represent $N$ concentration and $P$ concentration, respectively, and $N: P$ represents the mass ratio of $\mathrm{N}$ to $\mathrm{P}$. The bold values indicate significant effects $(P<0.05)$. n.a. means not available, due to lack of enough replicates for the ANOVA

\begin{tabular}{|llllllll|}
\hline Parameter & \multicolumn{7}{l}{ Source of variations } \\
\hline & $\mathrm{P}_{\mathrm{r}}$ & $\mathrm{N}_{\mathrm{f}}$ & $\mathrm{N}_{\mathrm{r}}$ & $\mathrm{P}_{\mathrm{r}} \times \mathrm{N}_{\mathrm{f}}$ & $\mathrm{P}_{\mathrm{r}} \times \mathrm{N}_{\mathrm{r}}$ & $\mathrm{N}_{\mathrm{f}} \times \mathrm{N}_{\mathrm{r}}$ & $\mathrm{P}_{\mathrm{r}} \times \mathrm{N}_{\mathrm{f}} \times \mathrm{N}_{\mathrm{r}}$ \\
\hline Shoot dry mass & $<0.001$ & 0.032 & 0.008 & 0.295 & 0.179 & 0.305 & 0.397 \\
\hline Root dry mass & $<0.001$ & 0.352 & $<0.001$ & 0.887 & $<0.001$ & 0.490 & 0.478 \\
\hline Root mass ratio & 0.001 & $<0.001$ & 0.004 & 0.322 & 0.464 & 0.853 & 0.945 \\
\hline Shoot [N] & $<0.001$ & $<0.001$ & $<0.001$ & $<0.001$ & 0.335 & 0.645 & 0.238 \\
\hline Root [N] & $<0.001$ & 0.007 & $<0.001$ & 0.719 & 0.084 & 0.699 & 0.416 \\
\hline Shoot [P] & $<0.001$ & 0.063 & $<0.001$ & 0.326 & 0.336 & 0.167 & 0.130 \\
\hline Root [P] & $<0.001$ & $<0.001$ & 0.001 & $<0.001$ & $<0.001$ & 0.265 & 0.183 \\
\hline Shoot N:P & $<0.001$ & 0.019 & 0.288 & 0.417 & 0.516 & 0.182 & 0.579 \\
\hline Rhizosheath tartrate & $<0.001$ & $<0.001$ & $<0.001$ & 0.117 & $<0.001$ & $<0.001$ & 0.117 \\
\hline Rhizosheath malonate & $<0.001$ & 0.609 & 0.040 & 0.238 & 0.369 & 0.761 & 0.498 \\
\hline Rhizosheath citrate & 0.927 & 0.952 & 0.586 & 0.471 & 0.618 & 0.414 & 0.594 \\
\hline Rhizosheath malate & $<0.001$ & 0.896 & $\mathbf{0 . 0 2 4}$ & 0.926 & n.a. & 0.160 & n.a. \\
\hline
\end{tabular}


The results of three-way ANOVA showed that, when $N$ was added, both shoot $[N]$ and root $[N]$ decreased significantly when $\mathrm{P}$ was added (both $P<0.001$ ), but increased considerably with increasing $\mathrm{N}$ rate (both $P<0.001)$ (Fig. 2, Table 1). There was a significant interaction between $\mathrm{P}$ rate and $\mathrm{N}$ form on shoot $[\mathrm{N}](P$ $<0.001$ ); among all four forms of $\mathrm{N}_{1} \mathrm{NH}_{4} \mathrm{NO}_{3}$ resulted in the greatest shoot $[\mathrm{N}]$ at $\mathrm{OP}$ but the least shoot $[\mathrm{N}]$ at 20P (Fig. 2a). Root [N] varied considerably with $\mathrm{N}$ form, and it was the greatest when $\mathrm{Ca}\left(\mathrm{NO}_{3}\right)_{2}$ was added (Fig. 2b). Based on the effect sizes, the effect of $P$ was positive on shoot $[N]$ but negative on root $[N]$, while the effect of $\mathrm{N}$ was always positive on both shoot $[\mathrm{N}]$ and root $[\mathrm{N}]$. The effect of the interaction between $\mathrm{P}$ and $\mathrm{N}$ on shoot [N] was always positive and sub-additive, but that on root $[\mathrm{N}]$ was negative and sub-additive in most treatments. Adding $\mathrm{P}$ weakened the positive effect of $\mathrm{N}$ on both shoot $[\mathrm{N}]$ and root $[\mathrm{N}]$ in almost all treatments.

When $\mathrm{N}$ was added, shoot [P] significantly increased when $\mathrm{P}$ supply was increased $(P<0.001)$, but it did not vary considerably with $\mathrm{N}$ form (Fig. 3a; Table 1$)$. Shoot [P] was also significantly affected by $\mathrm{N}$ rate $(P$ $<0.001$ ) and showed the lowest value at $25 \mathrm{~N}$, but did not show a consistent trend with increasing $\mathrm{N}$ rate. Root $[P]$ was significantly affected by the interactions between $P$ rate and $N$ form $(P<0.001)$, and between $\mathrm{P}$ rate and $\mathrm{N}$ rate $(P<0.001)$ (Fig. 3b; Table 1). Among all four forms of $\mathrm{N}$, root $[\mathrm{P}]$ was the lowest under $\mathrm{Ca}\left(\mathrm{NO}_{3}\right)_{2}$ and greatest under $\mathrm{NH}_{4} \mathrm{NO}_{3}$ at $\mathrm{OP}$, while it was the lowest under $\left(\mathrm{NH}_{4}\right)_{2} \mathrm{SO}_{4}$ and greatest under $\mathrm{CO}\left(\mathrm{NH}_{2}\right)_{2}$ at $20 \mathrm{P}$. Among the four $\mathrm{N}$ rates, $100 \mathrm{~N}$ resulted in the lowest root $[\mathrm{P}]$ at $\mathrm{OP}$ but the greatest $\operatorname{root}[\mathrm{P}]$ at 20P. As shown by the effect sizes, the effect of $\mathrm{P}$ was positive on both shoot $[\mathrm{P}]$ and root $[\mathrm{P}]$; the effect of $\mathrm{N}$ was positive on shoot $[\mathrm{P}]$ in all but one treatment and always positive on root $[\mathrm{P}]$. The effect of the interaction between $P$ and $N$ on shoot $[P]$ was always positive and sub-additive in all but one treatment, and that on root $[\mathrm{P}]$ was also always positive and sub-additive in most treatments. Adding $\mathrm{N}$ and $P$ together strengthened the positive effect of each other on both shoot $[P]$ and root $[P]$ in almost all treatments, except in some treatments at lower $\mathrm{N}$ rates, i.e. $25 \mathrm{~N}$ and $50 \mathrm{~N}$, where adding $\mathrm{N}$ weakened the positive effect of $P$ on shoot [P].

According to the results of three-way ANOVA, shoot N:P was significantly affected by $\mathrm{P}$ rate $(P<0.001)$ and $\mathrm{N}$ form $(P=0.019)$, but not by $\mathrm{N}$ rate (Fig. 4, Table 1$)$. Shoot $\mathrm{N}: \mathrm{P}$ declined markedly when $\mathrm{P}$ was added; among all four forms of $\mathrm{N}$, shoot $\mathrm{N}: \mathrm{P}$ was the highest when $\mathrm{Ca}\left(\mathrm{NO}_{3}\right)_{2}$ was added, and the lowest under $\mathrm{CO}\left(\mathrm{NH}_{2}\right)_{2}$. As shown by the effect sizes, the effect of $\mathrm{P}$ on shoot $\mathrm{N}: \mathrm{P}$ was negative, while the effect of $\mathrm{N}$ on shoot $\mathrm{N}: \mathrm{P}$ was positive in most treatments. The effect of the interaction between $\mathrm{P}$ and $\mathrm{N}$ was always negative, and additive or super-additive in most treatments. Root N:P was significantly affected by all three factors (all $P<0.001$ ) and all interactions (all $P \leq 0.017$ ) (Fig. S1, Table S1). The effect sizes showed that the effect of $\mathrm{P}$ on root $\mathrm{N}: \mathrm{P}$ was negative, while the effect of $\mathrm{N}$ on root N:P was always negative for all forms of $\mathrm{N}$, except $\mathrm{Ca}\left(\mathrm{NO}_{3}\right)_{2}$, for which the effect of $\mathrm{N}$ on root $\mathrm{N}: \mathrm{P}$ was positive under three out of the four $\mathrm{N}$ rates. The effect of the interaction between $\mathrm{P}$ and $\mathrm{N}$ was always negative, it was always sub-additive when $\mathrm{Ca}\left(\mathrm{NO}_{3}\right)_{2}$ was added, but additive and super-additive in most treatments when other forms of $\mathrm{N}$ were added. Adding $\mathrm{N}$ further strengthened the negative effect of $\mathrm{P}$ on root N:P (Fig. S1). 
We detected tartrate, malonate, citrate, and malate in the analyzed samples. The results of three-way ANOVA showed that, when $\mathrm{N}$ was added, the amount of tartrate was significantly affected by all three factors, and also by the interactions between $\mathrm{P}$ rate and $\mathrm{N}$ rate, and between $\mathrm{N}$ form and $\mathrm{N}$ rate (all $P<$ 0.001 ) (Fig. 5, Table 1). At $25 \mathrm{~N}$, the amount of tartrate was $81 \%$ less at $20 \mathrm{P}$ than at $0 \mathrm{P}$; at $100 \mathrm{~N}$, it was $69 \%$ less at $20 \mathrm{P}$ than at OP. At OP, the amount of tartrate was 12 times more at $100 \mathrm{~N}$ than at $0 \mathrm{~N}$; at $20 \mathrm{P}$, it was 21 times more at $100 \mathrm{~N}$ than at $0 \mathrm{~N}$. At both $25 \mathrm{~N}$ and $100 \mathrm{~N}$, among all four forms of $\mathrm{N}$, the amount of tartrate was the largest when $\mathrm{Ca}\left(\mathrm{NO}_{3}\right)_{2}$ was added, and the smallest under $\left(\mathrm{NH}_{4}\right)_{2} \mathrm{SO}_{4}$. For $\mathrm{Ca}\left(\mathrm{NO}_{3}\right)_{2}$, $\mathrm{NH}_{4} \mathrm{NO}_{3},\left(\mathrm{NH}_{4}\right)_{2} \mathrm{SO}_{4}$, and $\mathrm{CO}\left(\mathrm{NH}_{2}\right)_{2}$, the amount of tartrate was $13,19,16$, and 11 times greater at $100 \mathrm{~N}$ than at $25 \mathrm{~N}$, respectively. At $25 \mathrm{~N}$, when $\mathrm{Ca}\left(\mathrm{NO}_{3}\right)_{2}, \mathrm{NH}_{4} \mathrm{NO}_{3}$, and $\mathrm{CO}\left(\mathrm{NH}_{2}\right)_{2}$ was added, the amount of tartrate was 5.7, 3.6, and 3.8 times larger than when $\left(\mathrm{NH}_{4}\right)_{2} \mathrm{SO}_{4}$ was added, respectively; at $100 \mathrm{~N}$, it was $21,7.0$, and 6.9 times larger, respectively. The effect sizes showed that the effect of $P$ was slight when no $\mathrm{N}$ was added, while the effect of $\mathrm{N}$ was always positive, and the interactive effect of $\mathrm{P}$ and $\mathrm{N}$ was always positive and sub-additive. Adding $\mathrm{N}$ made the effect of $\mathrm{P}$ more negative, while adding $\mathrm{P}$ weakened the positive effect of $\mathrm{N}$.

When $\mathrm{N}$ was added, both $\mathrm{P}$ rate and $\mathrm{N}$ rate had a significant effect on the amounts of malonate $(P<0.001$ for $\mathrm{P}$ rate and $P=0.040$ for $\mathrm{N}$ rate, respectively) and malate $(P<0.001$ for $\mathrm{P}$ rate and $P=0.024$ for $\mathrm{N}$ rate, respectively) (Fig. 6, Table 1). The amount of malonate was $69 \%$ larger at $20 \mathrm{P}$ than at $0 \mathrm{P}$, and it was $22 \%$ smaller at $100 \mathrm{~N}$ than at $25 \mathrm{~N}$ (Fig. 6). Malate was detected at $25 \mathrm{~N}$, but not at $100 \mathrm{~N}$ at $\mathrm{OP}$, but it was detected at both $25 \mathrm{~N}$ and $100 \mathrm{~N}$ at $20 \mathrm{P}$; the amount at $25 \mathrm{~N}$ was $122 \%$ larger at $20 \mathrm{P}$ than at $0 \mathrm{P}$, while the amount at $20 \mathrm{P}$ was $39 \%$ smaller at $100 \mathrm{~N}$ than at $25 \mathrm{~N}$. The amount of citrate was not significantly affected by any of the three factors, or by any two-way or three-way interactions.

Correlations between the amounts of rhizosheath carboxylates and plant $\mathrm{N}$ and $\mathrm{P}$ nutrition

At both $0 \mathrm{P}$ and 20P, the amount of tartrate was significantly positively correlated with shoot $[\mathrm{N}](r=0.881$ and $P=0.002$ at $\mathrm{OP}$, and $r=0.843$ and $P=0.004$ at 20P, respectively) (Fig. 7a), shoot N:P ( $r=0.703$ and $P$ $=0.035$ at $0 \mathrm{P}$, and $r=0.691$ and $P=0.039$ at 20P, respectively) (Fig. 7b), and root $[\mathrm{N}](r=0.856$ and $P=$ 0.003 at $\mathrm{OP}$, and $r=0.844$ and $P=0.004$ at 20P, respectively) (Fig. S2). There were other significant correlations not shown in figures or tables, including a significant positive correlation between the amount of tartrate and root $[\mathrm{P}]$ at 20P $(r=0.667$ and $P=0.050)$, a significant negative correlation between the amount of malonate and root $[\mathrm{N}]$ at 20P $(r=-0.695$ and $P=0.038)$, a significant negative correlation between the amount of citrate and root N:P at 20P ( $r=-0.783$ and $P=0.013)$, and a significant negative correlation between the amount of malate and shoot $[\mathrm{P}]$ at 20P $(r=-0.699$ and $P=0.036)$.

\section{Discussion}

In the present study, the hypothesis that plant growth would be enhanced by $\mathrm{P}$ addition as well as $\mathrm{N}$ addition was not fully supported. Both shoot growth and root growth showed a positive response when $\mathrm{P}$ 
was added alone to the P-deficient soil, similar to the results of many other studies (He et al. 2017b; Pang et al. 2010; Pearse et al. 2006). When $\mathrm{N}$ was added alone, shoot growth always showed a positive response, but root growth showed a slightly negative response in most treatments. It is likely that $\mathrm{N}$ addition enhanced the photosynthetic capacity of the plants when no P was added (Evans 1983; Fleischer et al. 2013). However, a greater $\mathrm{N}$ supply did not invariably lead to a greater shoot biomass, likely because a lower $\mathrm{N}$ supply was already sufficient for alfalfa (Perring et al. 2008). When $\mathrm{P}$ was supplied, adding $\mathrm{N}$ weakened the positive effect of $\mathrm{P}$ on plant growth, and this effect was more obvious on root growth than on shoot growth, especially at $100 \mathrm{~N}$. The effect of $\mathrm{N}$ addition on biomass production in the present study differed from that reported by Li et al. (2016), who found that the P-enhanced biomass production in terrestrial ecosystems is greater under elevated $\mathrm{N}$ than under background $\mathrm{N}$, based on a meta-analysis of the effects of $\mathrm{P}$ addition, either alone or with $\mathrm{N}$ addition. The difference may be because we only studied alfalfa, a legume with a low exogenous demand for $\mathrm{N}$ but high demand for $\mathrm{P}$ (Haling et al. 2016; Valentine et al. 2017), while the meta-analysis of Li et al. (2016) covered many types of native vegtation. The results of Tian et al. (2020) showed that the effect of $\mathrm{N}$ addtion on plant biomass accumulation is functional group-dependent; $\mathrm{N}$ addition increased the abovegroud biomass of grasses and sedges, while it had little effect on that of forbs, and reduced that of $\mathrm{N}_{2}$-fixing forbs at the early phase of $\mathrm{N}$ addition. In the present study, a similar growth reduction might be expected, because alfalfa growth was limited by $\mathrm{P}$, even at 20P, as it has been found that dry mass and [P] of both shoots and roots of alfalfa could be further increased considerably by increasing $P$ supply to $80 \mathrm{mg} \mathrm{kg}^{-1}$ to the same loess soil (Peng et al. 2020), and P-limitation might restrict the positive response of plant growth to $\mathrm{N}$ addition. Furthermore, although $\mathrm{N}$ and $\mathrm{P}$ assimilation are closely coupled within plants (Evans 1983), adding $\mathrm{N}$ would increase the plants' demand for $\mathrm{P}$ and aggravate $\mathrm{P}$ deficiency, thus limiting biomass production (Li et al. 2016; Phoenix et al. 2004; Zhan et al. 2017).

Our results do not fully support the hypothesis that belowground biomass allocation would decrease with increasing $P$ rate, and also with increasing $N$ rate. The RMR of alfalfa in the present study showed a more $\mathrm{N}$-dependent than P-dependent response, which declined in response to almost all $\mathrm{N}$ supply rates at both $\mathrm{OP}$ and 20P, and tended to decline with increasing $\mathrm{N}$ rate at 20P. There are studies reporting that RMR declines with $\mathrm{N}$ addition (Li et al. 2020; Zhang et al. 2020). It is likely that, in the present study, in response to $\mathrm{N}$ addition, due to reduced $\mathrm{C}$ requirement for root biomass, the release of $\mathrm{C}$ by roots increased. We did not observe a negative relationship between RMR and P-fertilization in the present study, similar to the results in some previous studies on alfalfa growing in alkaline soils (He et al. 2017b; He et al. 2021), although often a greater RMR can enhance a plant's $P$ acquisition under P deficiency (Lynch and Ho 2005), and RMR usually declines with P-fertilization (Graciano et al. 2006; Poeplau et al. 2016). In contrast, RMR of alfalfa increased with P-fertilization in a loess soil, likely due to the plant's response to N-limitation induced by P-fertilization (Zhang et al. 2021). The hypothesis that plant [P] and $[N]$ would increase with increasing $P$ rate, and also with increasing $N$ rate was not fully supported. At the same $P$ rate, adding $N$ resulted in increased shoot $[N]$ and root $[N]$ in almost all treatments, except when $N$ was added as $\mathrm{NH}_{4} \mathrm{NO}_{3}$ at $25 \mathrm{mg} \mathrm{kg}^{-1}$ under 20P, and the effects were more significant at greater $\mathrm{N}$ rates. Adding P had a negative effect on root [N] compared with OP; it also weakened the positive effect of $\mathrm{N}$ on 
both shoot $[\mathrm{N}]$ and root $[\mathrm{N}]$, likely partly due to the "biological dilution effect" caused by P-enhanced biomass accumulation (He et al. 2017a).

Generally, when $\mathrm{P}$ or $\mathrm{N}$ was added alone, the effects of $\mathrm{P}$ and $\mathrm{N}$ on both shoot $[\mathrm{P}]$ and root $[\mathrm{P}]$ were positive; when $\mathrm{P}$ and $\mathrm{N}$ were added together, the positive effects were further strengthened, and the $\mathrm{N}$ induced biomass reduction might cause a "biological concentration effect" of $\mathrm{P}$ in plants, thus resulting in greater shoot and root $[\mathrm{P}]$ at greater $\mathrm{N}$ rates. Our suggestion of the "biological dilution effect" and "biological concentration effect" are partly supported by the results of plant $\mathrm{N}$ and $\mathrm{P}$ content, which were relatively stable when compared with the variation in plant biomass (Table S1, Fig. S3). There are studies showing that $\mathrm{N}$ addition results in greater plant $[\mathrm{N}]$ as well as $[\mathrm{P}]$, because the assimilation of $\mathrm{N}$ and $\mathrm{P}$ are closely coupled within plants (Evans 1983; Lü et al. 2013). The meta-analysis of Li et al. (2016) also showed that an increase in plant $[\mathrm{P}]$ induced by $\mathrm{P}$ addition is greater under elevated $\mathrm{N}$ than under background $N$. However, there are studies showing that $\mathrm{N}$ addition results in increased $[\mathrm{N}]$, but decreased [P] in plants (Li et al. 2019; Peng et al. 2017), while P addition does not affect plant [N] (Li et al. 2019). Some studies also showed that both $[\mathrm{N}]$ and $[\mathrm{P}]$ are greater in plants fertilized with $\mathrm{N}$ or $\mathrm{P}$ than in control plants not fertilized, and, surprsisingly, both $[\mathrm{N}]$ and $[\mathrm{P}]$ are greater in P-fertilized than in $\mathrm{N}$-fertilized plants (Graciano et al. 2006). The differences between the above-mentioned results are likely due to differences among plant species, soil type, as well as the rates and forms of $\mathrm{N}$ and $\mathrm{P}$ applied.

The hypothesis that plant N:P ratio would increase with increasing $N$ rate but decline with increasing $P$ rate was partly supported. At all $\mathrm{N}$ rates, $\mathrm{P}$ addition led to lower shoot and root $\mathrm{N}: \mathrm{P}$ ratios, while $\mathrm{N}$ addition led to greater shoot $\mathrm{N}: \mathrm{P}$ but lower root $\mathrm{N}: \mathrm{P}$ in most treatments. Plant $\mathrm{N}: \mathrm{P}$ ratio is an indicator of nutrient limitation of plant growth; $N: P$ ratios $<10$ and $>20$ tend to indicate that biomass production of terrestrial plants is N-or P-limited, respectively (Güsewell 2004; Koerselman and Meuleman 1996). Changes in N and/or $\mathrm{P}$ availability in soil can alter plant $\mathrm{N}: \mathrm{P}$ ratio, with $\mathrm{N}$ addition often increasing plant $\mathrm{N}: \mathrm{P}$ ratio and aggravating P-limitation, while $\mathrm{P}$ addition often reduces plant $\mathrm{N}: \mathrm{P}$ ratio and alleviates $\mathrm{P}$-limitation (Güsewell 2004; Zhang et al. 2013). In the present study, shoot N:P ratio was always $>20$ when no $P$ was added, indicating that plant growth was limited by $\mathrm{P}$; when $\mathrm{P}$ was added, shoot N:P ratio was between 10 and 20 in all but two treatments, indicating that P-limitation was alleviated.

The hypothesis that the amount of tartrate released by roots would decline with increasing P rate but increase with increasing $\mathrm{N}$ rate was partly supported by the results of the present study. Among the four carboxylates detected in the rhizosheath extracts, malonate was the most abundant one in the control and the 20P25N treatment, but tartrate became the most abundant one and increased dramatically when $\mathrm{N}$ was added alone and also when $\mathrm{N}$ was added at the greatest rate together with $\mathrm{P}$ (i.e. 20P100N). Tartrate is less commonly reported than citrate, malate, and malonate in studies on plant responses to Pdeficiency, and it has a much weaker capacity for P mobilization in a clay loam Ultisol than citrate (Wang et al. 2008). In the present study, when no $\mathrm{N}$ was added, the effect of $\mathrm{P}$ addition on tartrate release was negligible, but it was significantly negative when $\mathrm{N}$ was added, while the effect of $\mathrm{N}$ addition on tartrate release was almost always significantly positive, regardless of $\mathrm{P}$ supply. Compared with other carboxylates, the release of tartrate was more affected by soil $\mathrm{P}$ and $\mathrm{N}$ availability, similar to the results of 
He et al. (2020), in which alfalfa was grown in alkaline soils with low $\mathrm{P}$ and low $\mathrm{N}$ availability. For alfalfa grown in the present study, tartrate release might not be always associated with proton $\left(\mathrm{H}^{+}\right)$release, as shown by the rhizosheath $\mathrm{pH}$, which was not always lower than bulk soil $\mathrm{pH}$ and did not vary with either $\mathrm{P}$ supply or $\mathrm{N}$ supply as greatly as the amount of tartrate did (Table S1, Fig. S4). Possible strong buffering capacity of the loess soil could not explain the lack of the correlation between tartrate amount and the change in rhizosheath $\mathrm{pH}$, as both bulk soil $\mathrm{pH}$ and rhizosheath $\mathrm{pH}$ were strongly affected by $\mathrm{P}$ and $\mathrm{N}$ fertilization. It is likely that tartrate was released as an anion with accompanying cations other than $\mathrm{H}^{+}$, e.g. $\mathrm{K}^{+}$(Roelofs et al. 2001; Ryan et al. 1995).

The hypothesis that the amount of tartrate released by roots would have a closer relationship with plant $[\mathrm{N}]$ than with plant $[\mathrm{P}]$ was supported. The effect sizes and correlations all showed that $\mathrm{N}$ had a stronger effect than $\mathrm{P}$ on tartrate release. Soil $[\mathrm{N}]$ and $\mathrm{N}: \mathrm{P}$ ratio, rather than soil $[\mathrm{P}]$ affected the release of tartrate, as the amount of tartrate correlated significantly positively with soil [N] $(r=0.601$ and $P<0.001)$ and $\mathrm{N}: \mathrm{P}$ ratio ( $r=0.478$ and $P<0.001)$ (Fig. S5), but not with soil [P]. The results of the present study were in contrast with previous findings showing that the release of citrate and malate by lupins is controlled systemically by shoot or leaf [P] (Shane et al. 2008; Shen et al. 2003). Under 20P, there was a significantly negetive correlation between the amount of rhizosheath tartrate per unit RDM $(r=-0.693$ and $P=0.039)$ or the total amount of rhizosheath tartrate per pot $(r=-0.677$ and $P=0.045)$ and SDM of alfalfa in the present study (Fig. S6), indicating that release of more tartrate was associated with growth reduction. The correlation between tartrate amount and SDM was also negative under OP, but not significant $(P>0.5)$.

The increase of tartrate amount in response to $\mathrm{N}$ addition under both $\mathrm{OP}$ and 20P, the negetive correlation between tartrate amount and SDM, and the lack of a close relationship between tartrate amount and soil $[P]$ or plant $[P]$, suggest that $N$ addition likely resulted in more surplus $C$, which was then released as tartrate by roots. The release of tartrate was likely a way to discharge surplus $\mathrm{C}$ produced when the increase in photosynthate production exceeded the photosynthate demand for plant growth (Prescott et al. 2020). The increase in the amount of $C$ released by roots under elevated $N$ rate might be explained by the increased difference between the amount of $\mathrm{C}$ produced by photosynthesis and that of $\mathrm{C}$ required for growth at higher $\mathrm{N}$ rates in the present study. However, although Prescott et al. (2021) argued that rhizosphere 'trade' is an unnecessary analogy, and release of surplus $C$ under conditions that limit plant growth drives allocation and plant-soil interactions, in some situations, the production and release of certain C-containing compounds do have a specific effect, rather than disposal of surplus $\mathrm{C}$. For example, the release of carboxylates by the cluster roots of lupins (Lambers et al., 2013) and by the cluster or dauciform roots of Proteaceae or Cyperaceae, respectively (Lambers et al., 2011), is considered a pivotal mechanism to increase $\mathrm{P}$ acquisition under $\mathrm{P}$ deficiency. Therefore, the potential function of release of tartrate, and also other carboxylates, in P mobilization should not be dismissed (Wang and Lambers 2020). In the present study, plant [P] was increased by N-addition, indicating that adding $N$ induced greater $\mathrm{P}$ demand by the plants, such aggravated P-deficiency might also play a role, likely less important than discharging surplus $C$, in driving tartrate release. 
The hypothesis that the effects of $\mathrm{N}$ rate on the parameters investigated would depend on the forms of the added $\mathrm{N}$ was supported. In the present study, differences in effects among $\mathrm{N}$ forms were likely due to the preferential uptake of certain $\mathrm{N}$ forms by alfalfa. It is very likely that alfalfa preferentially took up $\mathrm{NO}_{3}{ }^{-}$ $\mathrm{N}$ from the loess soil compared with other $\mathrm{N}$ forms, since the loess soil is alkaline and has a high $\mathrm{Ca}$ content, while $\mathrm{NH}_{4}-\mathrm{N}$ was the least preferred (Gigon and Rorison 1972). This would explain why shoot [N] and $\mathrm{N}: \mathrm{P}$ ratio increased the most when $\mathrm{Ca}\left(\mathrm{NO}_{3}\right)_{2}$ was added, and the amount of tartrate was largest when $\mathrm{Ca}\left(\mathrm{NO}_{3}\right)_{2}$ was supplied, but smallest when $\left(\mathrm{NH}_{4}\right)_{2} \mathrm{SO}_{4}$ was added.

\section{Conclusions}

The findings of the present study demonstrate that the release of tartrate was enhanced in response to a greater soil $[\mathrm{N}]$ and $\mathrm{N}: \mathrm{P}$ ratio, and greater shoot $[\mathrm{N}]$ and $\mathrm{N}: \mathrm{P}$ ratio, which was likely a way to discharge surplus $\mathrm{C}$ produced by enhanced photosynthetic capacity induced by $\mathrm{N}$ addition when plant growth was limited by $\mathrm{P}$. The effects of $\mathrm{N}$ addition and its interaction with $\mathrm{P}$ addition on plant growth, $\mathrm{N}$ and $\mathrm{P}$ status, and tartrate release varied with $\mathrm{N}$ forms, due to preferential uptake of $\mathrm{NO}_{3}-\mathrm{N}$ over other $\mathrm{N}$ forms. These findings support the 'surplus C' hypothesis put forward by Prescott et al. (2020). However, it does not mean that a role of carboxylate release in $\mathrm{P}$ mobilization should be dismissed entirely.

\section{Declarations}

Funding

This work was financially supported by The National Key Research and Development Plan of China (2017YFC0504504), and The Natural Science Basic Research Program of Shaanxi Province (2019JM411).

Conflicts of interest/Competing interests

There is no conflicts of interest/competing interests to declare.

Availability of data and material

The data that support the findings of this study are available from the corresponding author upon reasonable request.

Author contributions

HH and QP designed the experiment. ZZ, QP, and RS set up the experiment, cultivated and harvested the plants. ZZ, RS, CC, XC, and YL analyzed the samples and collected the data. $\mathrm{HH}$ analyzed the data and wrote the manuscript. JP, SD, and HL interpretated the data and revised the manuscript.

\section{Acknowledgments}


Rhizosheath carboxylates were analyzed using The Biology Teaching and Research Core Facility at College of Life Sciences, Northwest A\&F University. We thank Xiyan Chen for helping the analysis of rhizosheath carboxylates using HPLC.

\section{References}

1. Abrahão A, Ryan MH, Laliberté E, Oliveira RS, Lambers H (2018) Phosphorus- and nitrogenacquisition strategies in two Bossiaea species (Fabaceae) along retrogressive soil chronosequences in south-western Australia. Physiol Plant 163:323-343. https://doi.org/10.1111/ppl.12704

2. Augusto L, Achat DL, Jonard M, Vidal D, Ringeval B (2017) Soil parent material-A major driver of plant nutrient limitations in terrestrial ecosystems. Global Change Biol 23:3808-3824. https://doi.org/10.1111/gcb.13691

3. Baker W, Thompson T (1992) Determination of total nitrogen in plant samples by Kjeldahl. In: Plank CO (ed) Plant Analysis Reference Procedures for the Southern Region of the United States. The University of Georgia Crop \& Soil Science Department, Athens, pp 13-16

4. Carvalhais LC, Dennis PG, Fedoseyenko D, Hajirezaei M-R, Borriss R, von Wirén N (2011) Root exudation of sugars, amino acids, and organic acids by maize as affected by nitrogen, phosphorus, potassium, and iron deficiency. J Plant Nutr Soil Sci 174:3-11. https://doi.org/10.1002/jpln.201000085

5. Evans JR (1983) Nitrogen and photosynthesis in the flag leaf of wheat (Triticum aestivum L.). Plant Physiol 72:297-302. https://doi.org/10.1104/pp.72.2.297

6. Fleischer K, Rebel KT, van der Molen MK, Erisman JW, Wassen MJ, van Loon EE, Montagnani L, Gough CM, Herbst M, Janssens IA, Gianelle D, Dolman AJ (2013) The contribution of nitrogen deposition to the photosynthetic capacity of forests. Global Biogeochem Cycles 27:187-199. https://doi.org/10.1002/gbc.20026

7. Gigon A, Rorison IH (1972) The response of some ecologically distinct plant species to nitrate- and to ammonium-nitrogen. J Ecol 60:93-102. https://doi.org/10.2307/2258043

8. Goodman WM, Spruill SE, Konnaroff E (2019) A proposed hybrid effect size plus $p$-value criterion: empirical evidence supporting its use. Am Stat 73:168-185.

https://doi.org/10.1080/00031305.2018.1564697

9. Graciano C, Goya JF, Frangi JL, Guiamet JJ (2006) Fertilization with phosphorus increases soil nitrogen absorption in young plants of Eucalyptus grandis. For Ecol Manag 236:202-210. https://doi.org/https://doi.org/10.1016/j.foreco.2006.09.005

10. Gupta AP, Neue HU, Singh VP (1993) Phosphorus determination in rice plants containing variable manganese content by the phospho-molybdo-vanadate (yellow) and phosphomolybdate (blue) colorimetric methods. Commun Soil Sci Plant Anal 24:1309-1318. https://doi.org/10.1080/00103629309368878 
11. Güsewell S (2004) N: P ratios in terrestrial plants: Variation and functional significance. New Phytol 164:243-266. https://doi.org/10.1111/j.1469-8137.2004.01192.x

12. Haling RE, Yang ZJ, Shadwell N, Culvenor RA, Stefanski A, Ryan MH, Sandral GA, Kidd DR, Lambers H, Simpson RJ (2016) Growth and root dry matter allocation by pasture legumes and a grass with contrasting external critical phosphorus requirements. Plant Soil 407:67-79. https://doi.org/10.1007/s11104-016-2808-2

13. Harpole WS, Ngai JT, Cleland EE, Seabloom EW, Borer ET, Bracken MES, Elser JJ, Gruner DS, Hillebrand H, Shurin JB, Smith JE (2011) Nutrient co-limitation of primary producer communities. Ecol Lett 14:852-862. https://doi.org/10.1111/j.1461-0248.2011.01651.x

14. He H, Dong Z, Peng Q, Wang X, Fan C, Zhang X (2017a) Impacts of coal fly ash on plant growth and accumulation of essential nutrients and trace elements by alfalfa (Medicago sativa) grown in a loessial soil. J Environ Manage 197:428-439. https://doi.org/10.1016/j.jenvman.2017.04.028

15. He H, Peng Q, Wang X, Fan C, Pang J, Lambers H, Zhang X (2017b) Growth, morphological and physiological responses of alfalfa (Medicago sativa) to phosphorus supply in two alkaline soils. Plant Soil 416:565-584. https://doi.org/10.1007/s11104-017-3242-9

16. He H, Wu M, Guo L, Fan C, Zhang Z, Su R, Peng Q, Pang J, Lambers H (2020) Release of tartrate as a major carboxylate by alfalfa (Medicago sativa L.) under phosphorus deficiency and the effect of soil nitrogen supply. Plant Soil 449:169-178. https://doi.org/10.1007/s11104-020-04481-9

17. He H, Wu M, Su R, Zhang Z, Chang C, Peng Q, Dong Z, Pang J, Lambers H (2021) Strong phosphorus $(P)$-zinc $(Z n)$ interactions in a calcareous soil-alfalfa system suggest that rational $P$ fertilization should be considered for Zn biofortification on Zn-deficient soils and phytoremediation of Zncontaminated soils. Plant Soil 461:119-134. https://doi.org/10.1007/s11104-020-04793-w

18. Hermans C, Hammond JP, White PJ, Verbruggen N (2006) How do plants respond to nutrient shortage by biomass allocation? Trends Plant Sci 11:610-617. https://doi.org/10.1016/j.tplants.2006.10.007

19. Hoch G, Körner C (2009) Growth and carbon relations of tree line forming conifers at constant vs. variable low temperatures. J Ecol 97:57-66. https://doi.org/10.1111/j.1365-2745.2008.01447.x

20. Huang G, Hayes PE, Ryan MH, Pang J, Lambers H (2017) Peppermint trees shift their phosphorusacquisition strategy along a strong gradient of plant-available phosphorus by increasing their transpiration at very low phosphorus availability. Oecologia 185:387-400. https://doi.org/10.1007/s00442-017-3961-x

21. Jiang M, Medlyn BE, Drake JE, Duursma RA, Anderson IC, Barton CVM, Boer MM, Carrillo Y, Castañeda-Gómez L, Collins L, Crous KY, De Kauwe MG, dos Santos BM, Emmerson KM, Facey SL, Gherlenda AN, Gimeno TE, Hasegawa S, Johnson SN, Kännaste A, Macdonald CA, Mahmud K, Moore BD, Nazaries L, Neilson EHJ, Nielsen UN, Niinemets Ü, Noh NJ, Ochoa-Hueso R, Pathare VS, Pendall E, Pihlblad J, Pineiro J, Powell JR, Power SA, Reich PB, Renchon AA, Riegler M, Rinnan R, Rymer PD, Salomon RL, Singh BK, Smith B, Tjoelker MG, Walker JKM, Wujeska-Klause A, Yang J, Zaehle S, 
Ellsworth DS (2020) The fate of carbon in a mature forest under carbon dioxide enrichment. Nature 580:227-231. https://doi.org/10.1038/s41586-020-2128-9

22. Karst J, Gaster J, Wiley E, Landhäusser SM (2017) Stress differentially causes roots of tree seedlings to exude carbon. Tree Physiol 37:154-164. https://doi.org/10.1093/treephys/tpw090

23. Koerselman W, Meuleman AFM (1996) The vegetation N:P ratio: a new tool to detect the nature of nutrient limitation. J Appl Ecol 33:1441-1450. https://doi.org/10.2307/2404783

24. Körner C (2015) Paradigm shift in plant growth control. Curr Opin Plant Biol 25:107-114. https://doi.org/10.1016/j.pbi.2015.05.003

25. Lambers H, Clements JC, Nelson MN (2013) How a phosphorus-acquisition strategy based on carboxylate exudation powers the success and agronomic potential of lupines (Lupinus, Fabaceae). Am J Bot 100:263-288. https://doi.org/10.3732/ajb.1200474

26. Lambers H, Finnegan PM, Laliberté E, Pearse SJ, Ryan MH, Shane MW, Veneklaas EJ (2011) Phosphorus nutrition of Proteaceae in severely phosphorus-impoverished soils: Are there lessons to be learned for future crops? Plant Physiol 156:1058-1066. https://doi.org/10.1104/pp.111.174318

27. Lambers H, Plaxton WC (2015) Phosphorus: Back to the roots. Phosphorus Metabolism in Plants 48:3-22. https://doi.org/10.1002/9781118958841.ch1

28. Li L, Liu B, Gao X, Li X, Li C (2019) Nitrogen and phosphorus addition differentially affect plant ecological stoichiometry in desert grassland. Sci Rep-UK 9:18673. https://doi.org/10.1038/s41598019-55275-8

29. Li P, Yin R, Shang B, Agathokleous E, Zhou H, Feng Z (2020) Interactive effects of ozone exposure and nitrogen addition on tree root traits and biomass allocation pattern: An experimental case study and a literature meta-analysis. Sci Total Environ 710.

https://doi.org/10.1016/j.scitotenv.2019.136379

30. Li Y, Niu SL, Yu GR (2016) Aggravated phosphorus limitation on biomass production under increasing nitrogen loading: a meta-analysis. Global Change Biol 22:934-943. https://doi.org/10.1111/gcb.13125

31. Litton CM, Raich JW, Ryan MG (2007) Carbon allocation in forest ecosystems. Global Change Biol 13:2089-2109. https://doi.org/10.1111/j.1365-2486.2007.01420.x

32. Lü XT, Reed S, Yu Q, He NP, Wang ZW, Han XG (2013) Convergent responses of nitrogen and phosphorus resorption to nitrogen inputs in a semiarid grassland. Global Change Biol 19:27752784. https://doi.org/10.1111/gcb.12235

33. Lynch JP, Ho MD (2005) Rhizoeconomics: Carbon costs of phosphorus acquisition. Plant Soil 269:45-56. https://doi.org/10.1007/s11104-004-1096-4

34. McDowell NG (2011) Mechanisms linking drought, hydraulics, carbon metabolism, and vegetation mortality. Plant Physiol 155:1051-1059. https://doi.org/10.1104/pp.110.170704

35. Muller B, Pantin F, Génard M, Turc O, Freixes S, Piques M, Gibon Y (2011) Water deficits uncouple growth from photosynthesis, increase $\mathrm{C}$ content, and modify the relationships between $\mathrm{C}$ and growth in sink organs. J Exp Bot 62:1715-1729. https://doi.org/10.1093/jxb/erq438 
36. Ngwene B, George E, Claussen W, Neumann E (2010) Phosphorus uptake by cowpea plants from sparingly available or soluble sources as affected by nitrogen form and arbuscular-mycorrhizafungal inoculation. J Plant Nutr Soil Sci 173:353-359. https://doi.org/10.1002/jpln.200900203

37. Niu YF, Chai RS, Dong HF, Wang $\mathrm{H}$, Tang CX, Zhang YS (2013) Effect of elevated $\mathrm{CO}_{2}$ on phosphorus nutrition of phosphate-deficient Arabidopsis thaliana (L.) Heynh under different nitrogen forms. J Exp Bot 64:355-367. https://doi.org/10.1093/jxb/ers341

38. Oburger E, Leitner D, Jones DL, Zygalakis KC, Schnepf A, Roose T (2011) Adsorption and desorption dynamics of citric acid anions in soil. Eur J Soil Sci 62:733-742. https://doi.org/10.1111/j.13652389.2011.01384.x

39. Pandey R, Meena SK, Krishnapriya V, Ahmad A, Kishora N (2014) Root carboxylate exudation capacity under phosphorus stress does not improve grain yield in green gram. Plant Cell Rep 33:919-928. https://doi.org/10.1007/s00299-014-1570-2

40. Pang J, Ryan MH, Siddique KHM, Simpson RJ (2017) Unwrapping the rhizosheath. Plant Soil 418:129-139. https://doi.org/10.1007/s11104-017-3358-y

41. Pang JY, Tibbett M, Denton MD, Lambers H, Siddique KHM, Bolland MDA, Revell CK, Ryan MH (2010) Variation in seedling growth of 11 perennial legumes in response to phosphorus supply. Plant Soil 328:133-143. https://doi.org/10.1007/s11104-009-0088-9

42. Pearse SJ, Veneklaas EJ, Cawthray G, Bolland MDA, Lambers H (2006) Triticum aestivum shows a greater biomass response to a supply of aluminium phosphate than Lupinus albus, despite releasing fewer carboxylates into the rhizosphere. New Phytol 169:515-524. https://doi.org/10.1111/j.14698137.2005.01614.x

43. Pearse SJ, Veneklaas EJ, Cawthray G, Bolland MDA, Lambers H (2007) Carboxylate composition of root exudates does not relate consistently to a crop species' ability to use phosphorus from aluminium, iron or calcium phosphate sources. New Phytol 173:181-190. https://doi.org/10.1111/j.1469-8137.2006.01897.x

44. Peng Q, He H, Fan C, Wu M, Guo L, Wang X, Zhang X (2020) The interaction of phosphate and selenite in alkaline soil and accumulation by alfalfa (Medicago sativa L.). Arch Agron Soil Sci 67:122-135. https://doi.org/10.1080/03650340.2020.1718112

45. Peng Y, Li F, Zhou G, Fang K, Zhang D, Li C, Yang G, Wang G, Wang J, Yang Y (2017) Linkages of plant stoichiometry to ecosystem production and carbon fluxes with increasing nitrogen inputs in an alpine steppe. Global Change Biol 23:5249-5259. https://doi.org/10.1111/gcb.13789

46. Perring MP, Hedin LO, Levin SA, McGroddy M, de Mazancourt C (2008) Increased plant growth from nitrogen addition should conserve phosphorus in terrestrial ecosystems. Proc Natl Acad Sci U S A 105:1971-1976. https://doi.org/10.1073/pnas.0711618105

47. Phoenix GK, Booth RE, Leake JR, Read DJ, Grime JP, Lee JA (2004) Simulated pollutant nitrogen deposition increases $\mathrm{P}$ demand and enhances root-surface phosphatase activities of three plant functional types in a calcareous grassland. New Phytol 161:279-289. https://doi.org/10.1046/j.1469-8137.2003.00910.x 
48. Poeplau C, Bolinder MA, Kirchmann H, Kätterer T (2016) Phosphorus fertilisation under nitrogen limitation can deplete soil carbon stocks: evidence from Swedish meta-replicated long-term field experiments. Biogeosciences 13:1119-1127. https://doi.org/10.5194/bg-13-1119-2016

49. Prescott CE, Grayston SJ, Helmisaari HS, Kaštovská E, Körner C, Lambers H, Meier IC, Millard $P$, Ostonen I (2020) Surplus carbon drives allocation and plant-soil interactions. Trends Ecol Evol 35:1110-1118. https://doi.org/10.1016/j.tree.2020.08.007

50. Prescott CE, Grayston SJ, Helmisaari HS, Kaštovská E, Körner C, Lambers H, Meier IC, Millard P, Ostonen I (2021) Rhizosphere 'trade' is an unnecessary analogy: Response to Noë. Trends Ecol Evol 36:176-177. https://doi.org/10.1016/j.tree.2020.12.005

51. Roelofs RFR, Rengel Z, Cawthray GR, Dixon KW, Lambers H (2001) Exudation of carboxylates in Australian Proteaceae: chemical composition. Plant Cell Environ 24:891-903. https://doi.org/10.1046/j.1365-3040.2001.00741.x

52. Ryan PR, Delhaize E, Randall PJ (1995) Characterisation of Al-stimulated efflux of malate from the apices of Al-tolerant wheat roots. Planta 196:103-110. https://doi.org/10.1007/BF00193223

53. Ryan PR, James RA, Weligama C, Delhaize E, Rattey A, Lewis DC, Bovill WD, McDonald G, Rathjen TM, Wang E, Fettell NA, Richardson AE (2014) Can citrate efflux from roots improve phosphorus uptake by plants? Testing the hypothesis with near-isogenic lines of wheat. Physiol Plant 151:230242. https://doi.org/10.1111/ppl.12150

54. Shane MW, Lambers H, Cawthray GR, Kuhn AJ, Schurr U (2008) Impact of phosphorus mineral source (Al-P or Fe-P) and pH on cluster-root formation and carboxylate exudation in Lupinus albus $\mathrm{L}$. Plant Soil 304:169-178. https://doi.org/10.1007/s11104-007-9535-7

55. Sharma M, Pang JY, Wen ZH, De Borda A, Kim HS, Liu YF, Lambers H, Ryan MH, Siddique KHM (2021) A significant increase in rhizosheath carboxylates and greater specific root length in response to terminal drought is associated with greater relative phosphorus acquisition in chickpea. Plant Soil 460:51-68. https://doi.org/10.1007/s11104-020-04776-x

56. Shen J, Rengel Z, Tang C, Zhang F (2003) Role of phosphorus nutrition in development of cluster roots and release of carboxylates in soil-grown Lupinus albus. Plant Soil 248:199-206. https://doi.org/10.1023/a:1022375229625

57. Suriyagoda LDB, Lambers H, Renton M, Ryan MH (2012) Growth, carboxylate exudates and nutrient dynamics in three herbaceous perennial plant species under low, moderate and high phosphorus supply. Plant Soil 358:100-112. https://doi.org/10.1007/s11104-012-1311-7

58. Tian Q, Yang L, Ma P, Zhou H, Liu N, Bai W, Wang H, Ren L, Lu P, Hanl W, Schultz PA, Bever JD, Zhang F-S, Lambers H, Zhang W-H (2020) Below-ground-mediated and phase-dependent processes drive nitrogen-evoked community changes in grasslands. J Ecol 108:1874-1887. https://doi.org/10.1111/1365-2745.13415

59. Valentine AJ, Kleinert A, Benedito VA (2017) Adaptive strategies for nitrogen metabolism in phosphate deficient legume nodules. Plant Sci (Amsterdam Neth) 256:46-52. https://doi.org/10.1016/j.plantsci.2016.12.010 
60. van Dam NM, Bouwmeester HJ (2016) Metabolomics in the rhizosphere: tapping into belowground chemical communication. Trends Plant Sci 21:256-265.

https://doi.org/10.1016/j.tplants.2016.01.008

61. Wang XJ, Guppy CN, Watson L, Sale PWG, Tang CX (2011) Availability of sparingly soluble phosphorus sources to cotton (Gossypium hirsutum L.), wheat (Triticum aestivum L.) and white lupin (Lupinus albus $\mathrm{L}$.) with different forms of nitrogen as evaluated by a ${ }^{32} \mathrm{P}$ isotopic dilution technique. Plant Soil 348:85-98. https://doi.org/10.1007/s11104-011-0901-0

62. Wang Y, He Y, Zhang H, Schroder J, Li C, Zhou D (2008) Phosphate mobilization by citric, tartaric, and oxalic acids in a clay loam Ultisol. Soil Sci Soc Am J 72:1263-1268.

https://doi.org/https://doi.org/10.2136/sssaj2007.0146

63. Wang Y, Krogstad T, Clarke JL, Hallama M, Øgaard AF, Eich-Greatorex S, Kandeler E, Clarke N (2016) Rhizosphere organic anions play a minor role in improving crop species' ability to take up residual phosphorus $(P)$ in agricultural soils low in $\mathrm{P}$ availability. Front Plant Sci 7:1664. https://doi.org/10.3389/fpls.2016.01664

64. Wang YL, Lambers $H$ (2020) Root-released organic anions in response to low phosphorus availability: recent progress, challenges and future perspectives. Plant Soil 447:135-156. https://doi.org/10.1007/s11104-019-03972-8

65. Weisskopf L, Abou-Mansour E, Fromin N, Tomasi N, Santelia D, Edelkott I, Neumann G, Aragno M, Tabacchi R, Martinoia E (2006) White lupin has developed a complex strategy to limit microbial degradation of secreted citrate required for phosphate acquisition. Plant Cell Environ 29:919-927. https://doi.org/10.1111/j.1365-3040.2005.01473.x

66. Wen ZH, Pang JY, Tueux G, Liu YF, Shen JB, Ryan MH, Lambers H, Siddique KHM (2020) Contrasting patterns in biomass allocation, root morphology and mycorrhizal symbiosis for phosphorus acquisition among 20 chickpea genotypes with different amounts of rhizosheath carboxylates. Funct Ecol 34:1311-1324. https://doi.org/10.1111/1365-2435.13562

67. Zhan S, Wang Y, Zhu Z, Li W, Bai Y (2017) Nitrogen enrichment alters plant N: P stoichiometry and intensifies phosphorus limitation in a steppe ecosystem. Environ Exp Bot 134:21-32. https://doi.org/10.1016/j.envexpbot.2016.10.014

68. Zhang J, Zuo X, Zhao X, Ma J, Medina-Roldán E (2020) Effects of rainfall manipulation and nitrogen addition on plant biomass allocation in a semiarid sandy grassland. Sci Rep-UK 10:9026. https://doi.org/10.1038/s41598-020-65922-0

69. Zhang N, Guo R, Song P, Guo J, Gao Y (2013) Effects of warming and nitrogen deposition on the coupling mechanism between soil nitrogen and phosphorus in Songnen Meadow Steppe, northeastern China. Soil Biol Biochem 65:96-104. https://doi.org/10.1016/j.soilbio.2013.05.015

70. Zhang Z, Su R, Chang C, Cheng X, Peng Q, Lambers H, He H (2021) Effects of oxytetracycline on plant growth, phosphorus uptake, and carboxylates in the rhizosheath of alfalfa. Plant Soil 461:501515. https://doi.org/10.1007/s11104-021-04840-0 
Figures
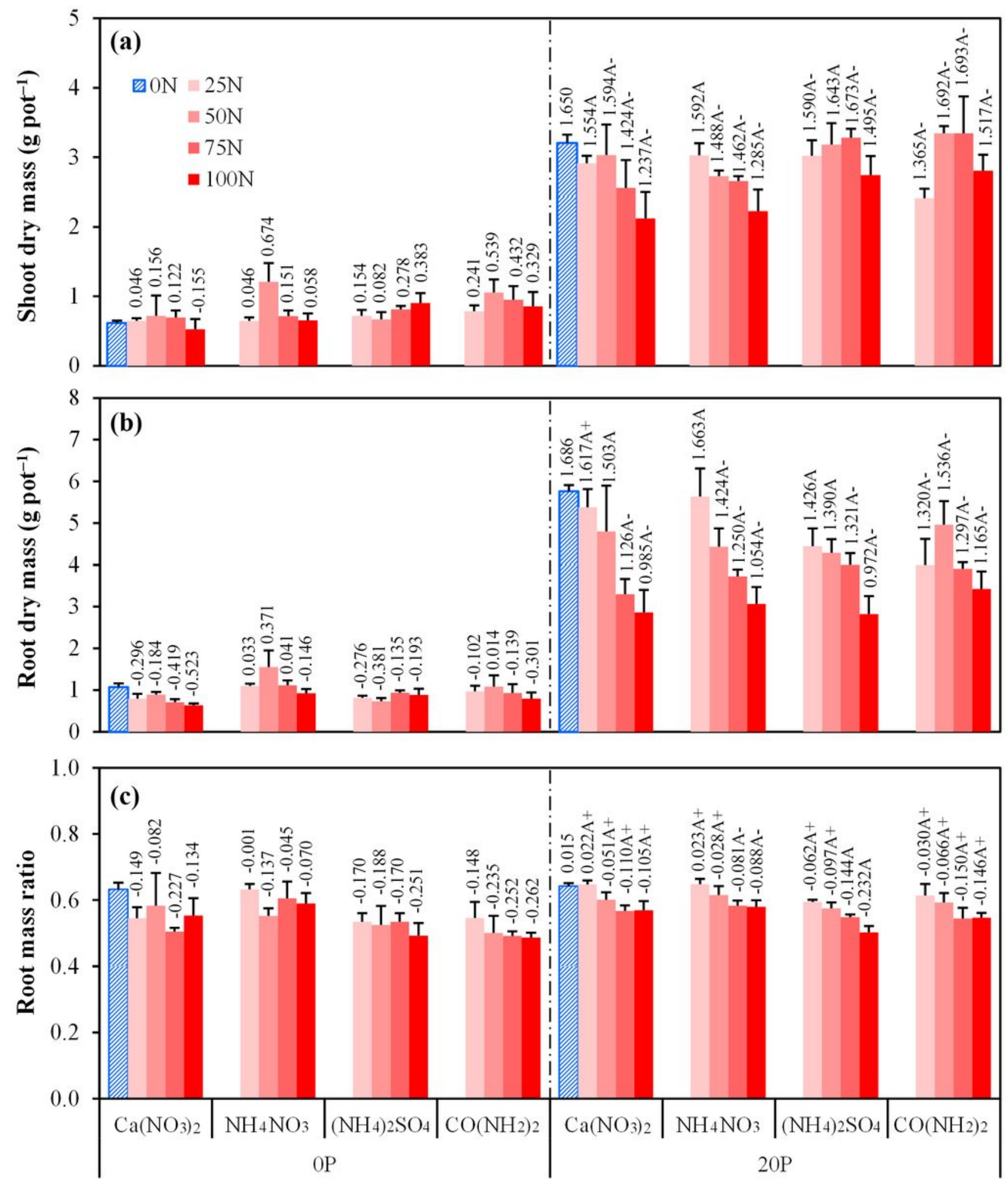

Figure 1

Shoot dry mass (a), root dry mass (b), and root mass ratio (c) of alfalfa grown in a loess soil in a greenhouse with different rates of added phosphorus $(P)$ and nitrogen $(N)$ in four forms. OP and 20P represent that $P$ was added at 0 and $20 \mathrm{mg} \mathrm{kg}-1$ as $\mathrm{KH} 2 \mathrm{PO} 4$, respectively; $0 \mathrm{~N}, 25 \mathrm{~N}, 50 \mathrm{~N}, 75 \mathrm{~N}$, and $100 \mathrm{~N}$ 
represent that $\mathrm{N}$ was added at $0,25,50,75$, and $100 \mathrm{mg} \mathrm{kg}-1$, respectively. Data are presented as means $+\operatorname{SE}(n=4)$. Numbers above the bars are effect sizes of the treatments; $A, A$-, and A+ following the numbers indicate the effects of $\mathrm{N}$ and $\mathrm{P}$ were additive, sub-additive, and super-additive, respectively
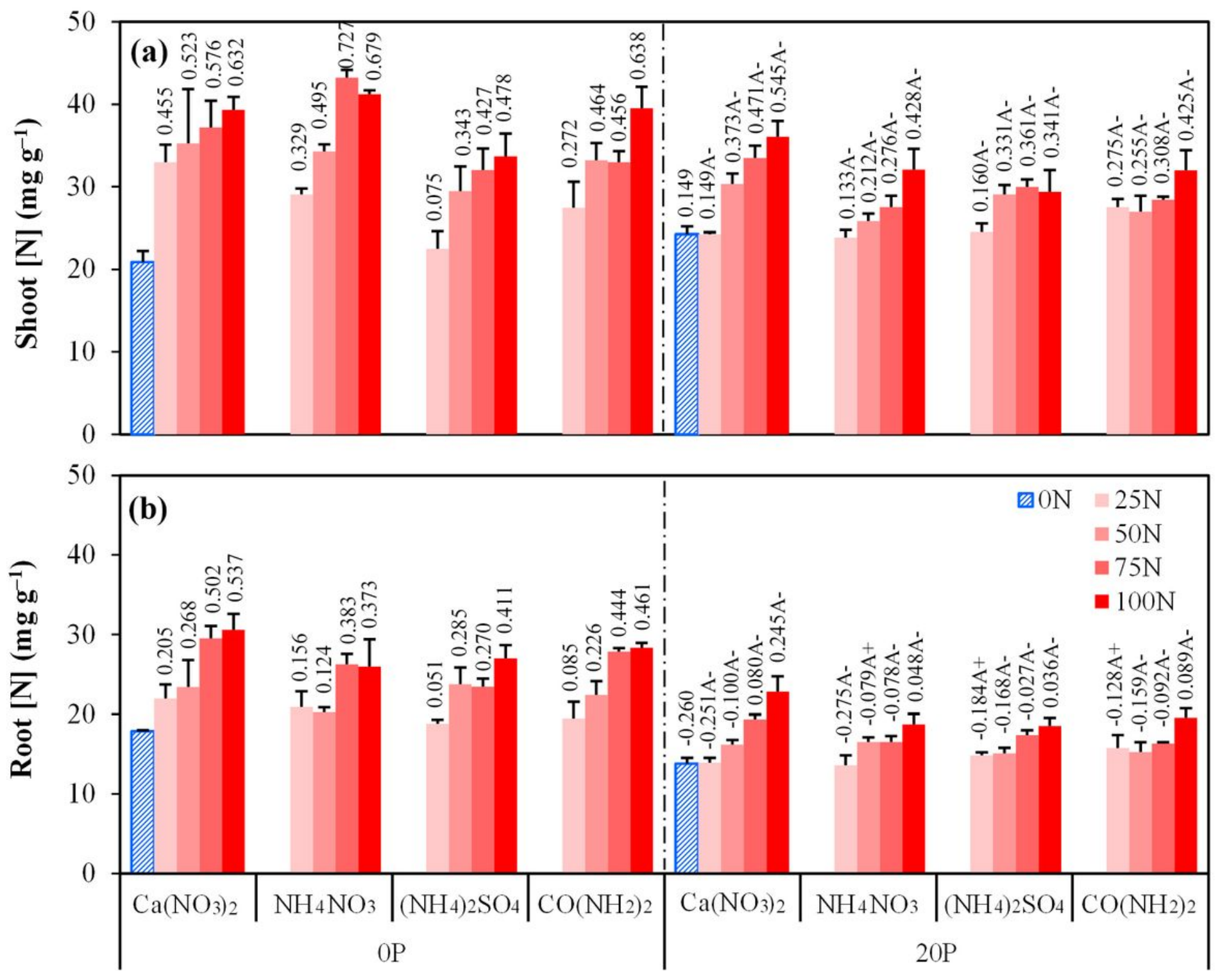

\section{Figure 2}

Shoot nitrogen concentration ([N]) (a) and root [N] (b) of alfalfa grown in a loess soil in a greenhouse with different rates of added phosphorus $(\mathrm{P})$ and $\mathrm{N}$ in four forms. $\mathrm{OP}$ and 20P represent that $\mathrm{P}$ was added at 0 and $20 \mathrm{mg} \mathrm{kg}-1$ as $\mathrm{KH} 2 \mathrm{PO}$, respectively; $0 \mathrm{~N}, 25 \mathrm{~N}, 50 \mathrm{~N}, 75 \mathrm{~N}$, and $100 \mathrm{~N}$ represent that $\mathrm{N}$ was added at 0 , $25,50,75$, and $100 \mathrm{mg} \mathrm{kg}-1$, respectively. Data are presented as means $+\mathrm{SE}(\mathrm{n}=4)$. Numbers above the bars are effect sizes of the treatments; $A, A$, and $A+$ following the numbers indicate the effects of $N$ and $P$ were additive, sub-additive, and super-additive, respectively 

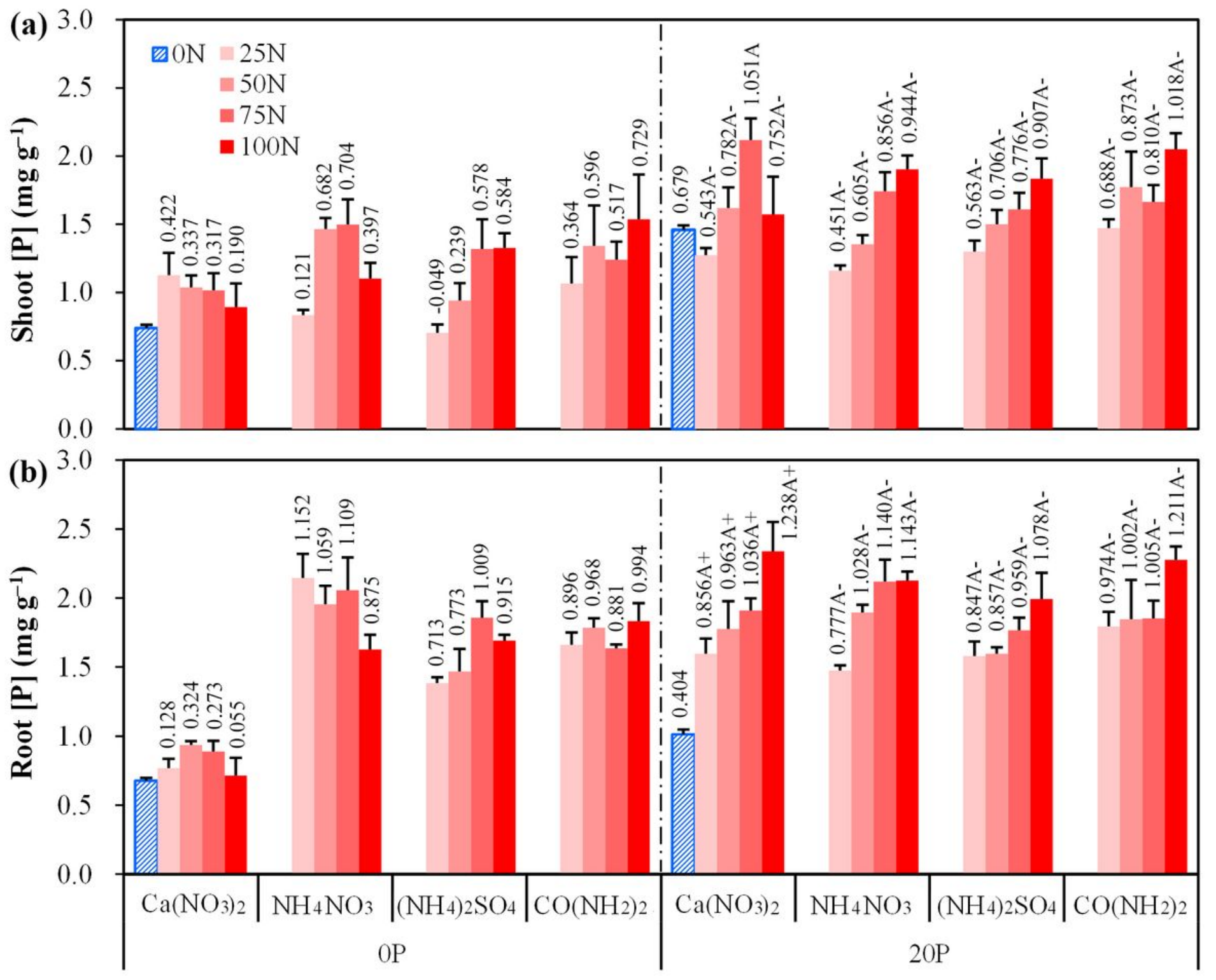

Figure 3

Shoot phosphorus concentration ([P]) (a) and root [P] (b) of alfalfa grown in a loess soil in a greenhouse with different rates of added $\mathrm{P}$ and nitrogen $(\mathrm{N})$ in four forms. OP and 20P represent that $\mathrm{P}$ was added at 0 and $20 \mathrm{mg} \mathrm{kg}-1$ as $\mathrm{KH} 2 \mathrm{PO} 4$, respectively; $0 \mathrm{~N}, 25 \mathrm{~N}, 50 \mathrm{~N}, 75 \mathrm{~N}$, and $100 \mathrm{~N}$ represent that $\mathrm{N}$ was added at $0,25,50,75$, and $100 \mathrm{mg} \mathrm{kg}-1$, respectively. Data are presented as means $+S E(n=4)$. Numbers above the bars are effect sizes of the treatments; $A, A$, and $A+$ following the numbers indicate the effects of $N$ and $\mathrm{P}$ were additive, sub-additive, and super-additive, respectively 


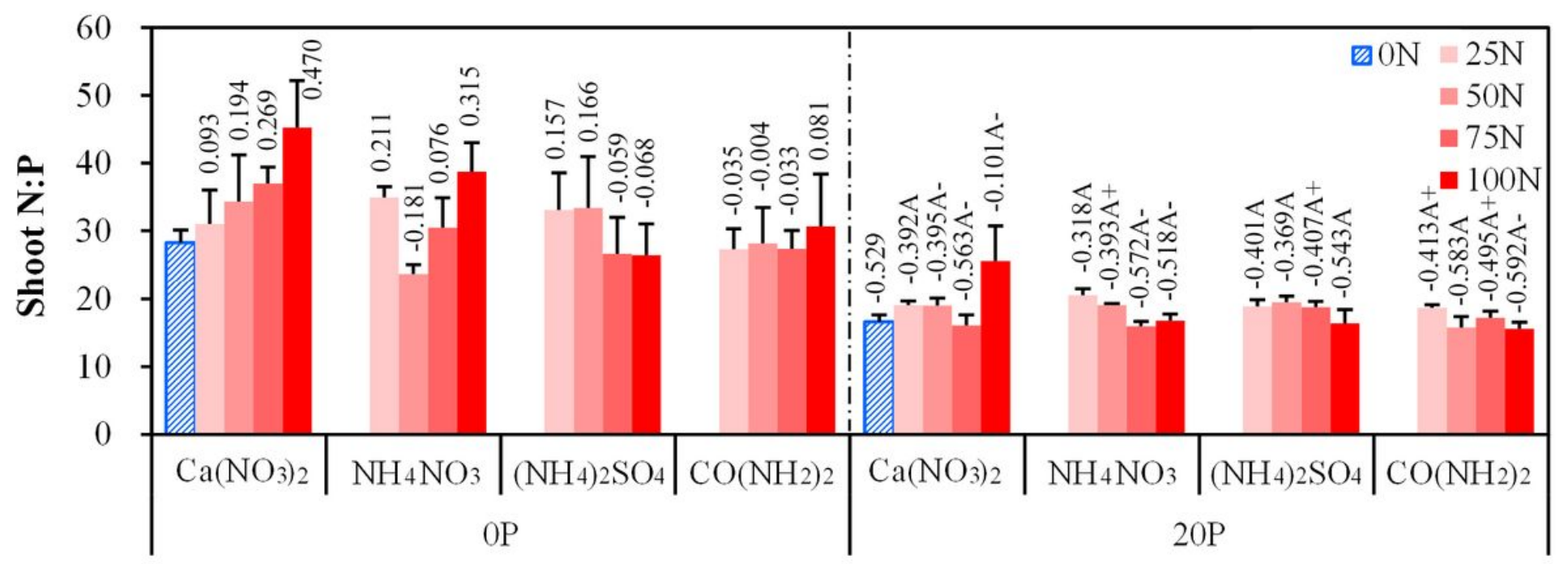

Figure 4

Shoot nitrogen to phosphorus mass ratio $(N: P)$ of alfalfa grown in a loess soil in a greenhouse with different rates of added $\mathrm{P}$ and $\mathrm{N}$ in four forms. $\mathrm{OP}$ and 20P represent that $\mathrm{P}$ was added at 0 and $20 \mathrm{mg}$ $\mathrm{kg}-1$ as $\mathrm{KH} 2 \mathrm{PO} 4$, respectively; $0 \mathrm{~N}, 25 \mathrm{~N}, 50 \mathrm{~N}, 75 \mathrm{~N}$, and $100 \mathrm{~N}$ represent that $\mathrm{N}$ was added at $0,25,50,75$, and $100 \mathrm{mg} \mathrm{kg}-1$, respectively. Data are presented as means + SE $(n=4)$. Numbers above the bars are effect sizes of the treatments; $A, A-$ and $A+$ following the numbers indicate the effects of $N$ and $P$ were additive, sub-additive, and super-additive, respectively

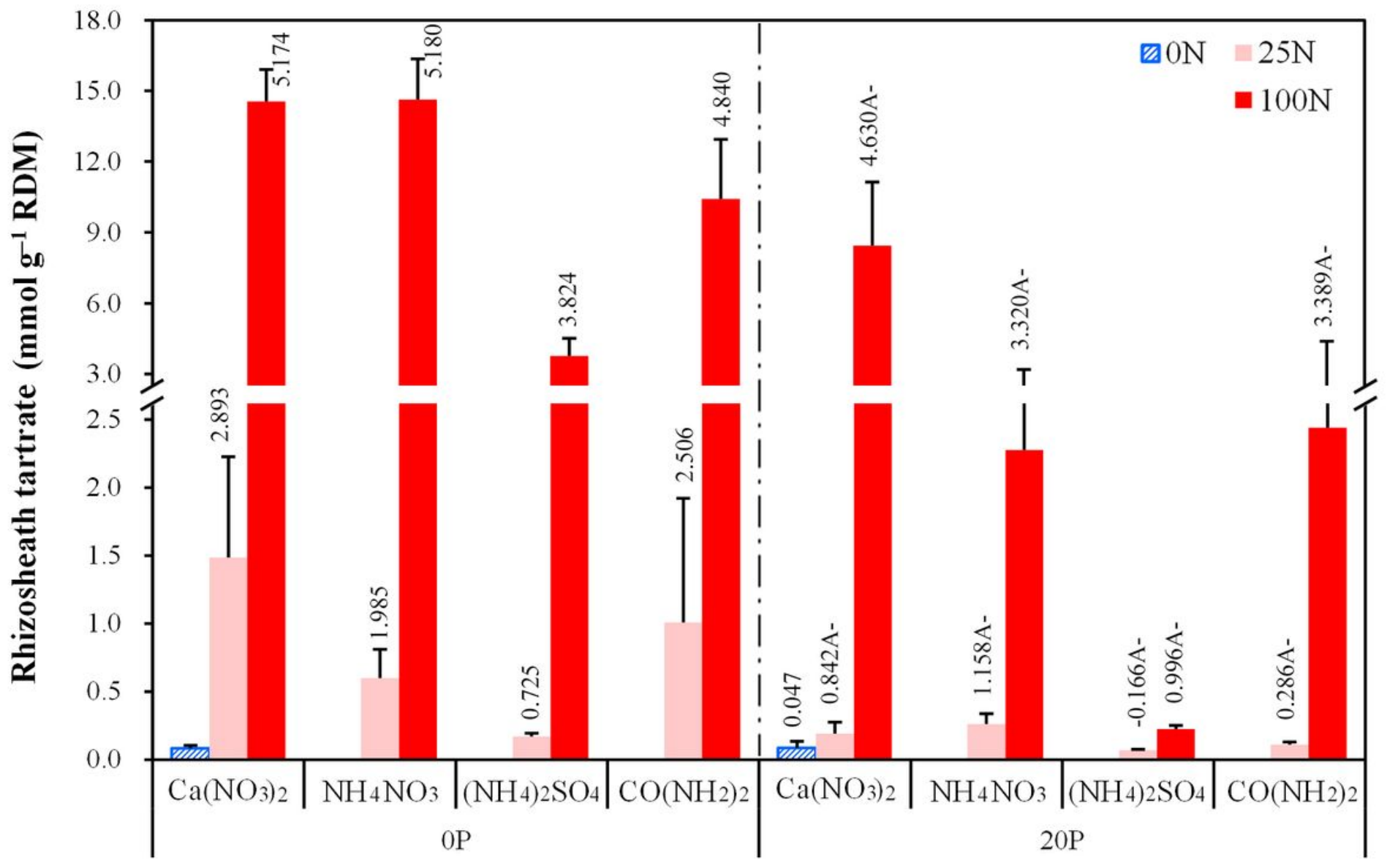




\section{Figure 5}

The amount of tartrate in the rhizosheath of alfalfa grown in a loess soil in a greenhouse with different rates of added phosphorus $(\mathrm{P})$ and nitrogen $(\mathrm{N})$ in four forms. OP and 20P represent that $\mathrm{P}$ was added at 0 and $20 \mathrm{mg} \mathrm{kg}-1$ as $\mathrm{KH} 2 \mathrm{PO}$, respectively; $0 \mathrm{~N}, 25 \mathrm{~N}, 50 \mathrm{~N}, 75 \mathrm{~N}$, and $100 \mathrm{~N}$ represent that $\mathrm{N}$ was added at $0,25,50,75$, and $100 \mathrm{mg} \mathrm{kg}-1$, respectively. Data are presented as means $+S E(n=4$, except for some treatments in which tartrate was not detected in all samples). Numbers above the bars are effect sizes of the treatments; $A, A$, and $A+$ following the numbers indicate the effects of $N$ and $P$ were additive, subadditive, and super-additive, respectively

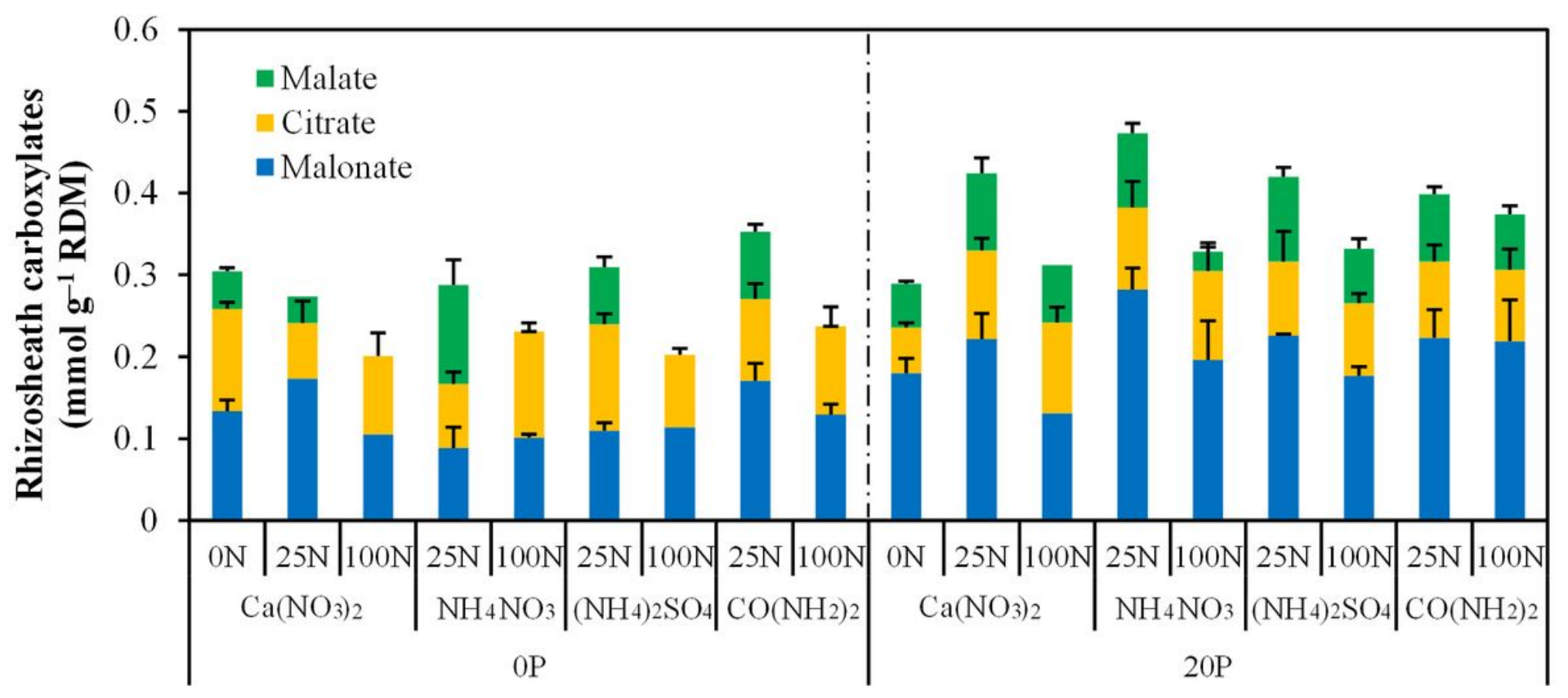

Figure 6

The amounts malonate, citrate, and malate in the rhizosheath of alfalfa grown in a loess soil in a greenhouse with different rates of added phosphorus $(\mathrm{P})$ and nitrogen $(\mathrm{N})$ in four forms. OP and 20P represent that $P$ was added at 0 and $20 \mathrm{mg} \mathrm{kg}-1$ as $\mathrm{KH} 2 \mathrm{PO} 4$, respectively; $0 \mathrm{~N}, 25 \mathrm{~N}, 50 \mathrm{~N}, 75 \mathrm{~N}$, and $100 \mathrm{~N}$ represent that $\mathrm{N}$ was added at $0,25,50,75$, and $100 \mathrm{mg} \mathrm{kg}-1$, respectively. Data are presented as means $+\operatorname{SE}(n=4$, except for some treatments in which certain carboxylate was not detected in all samples) 

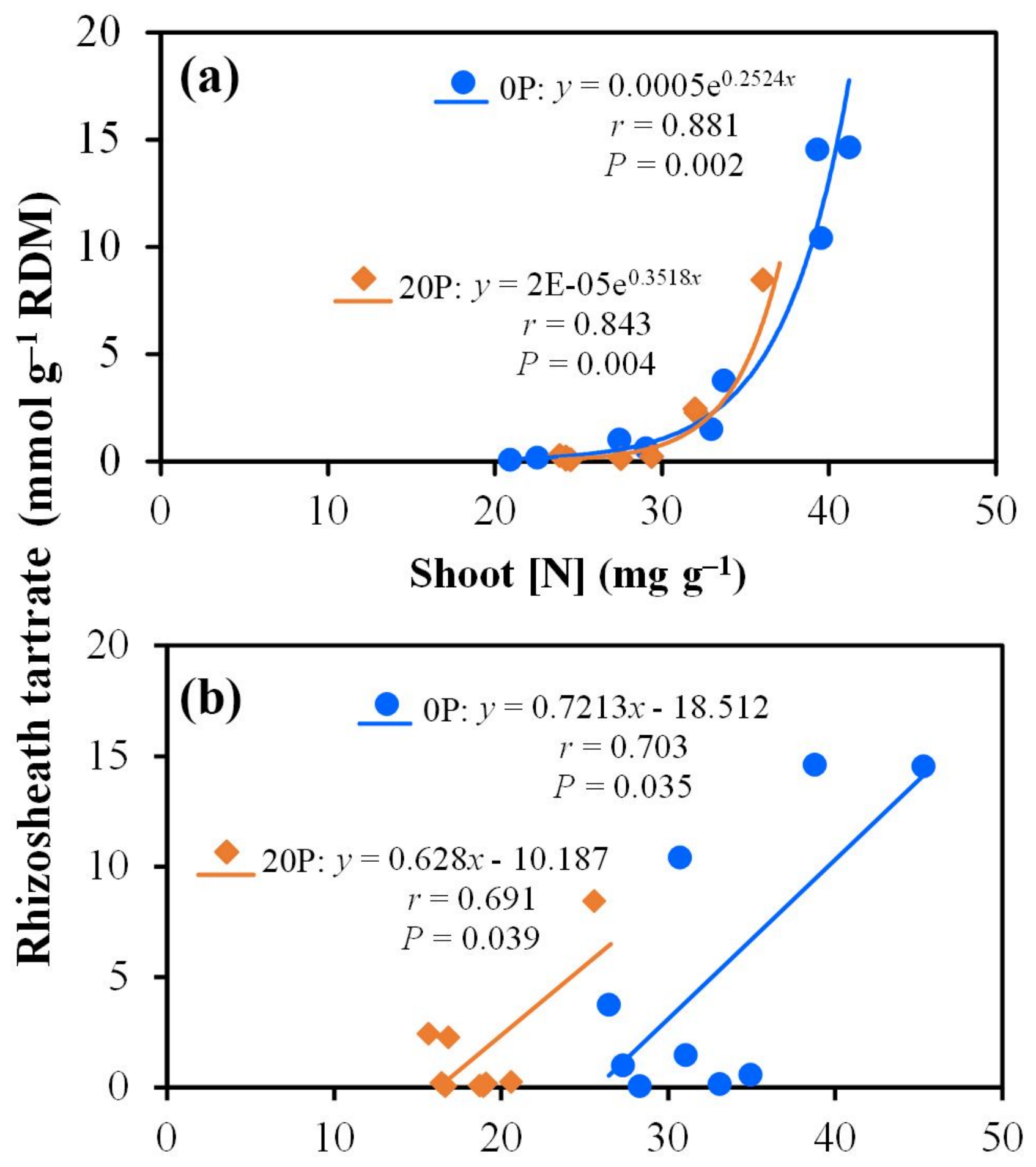

Shoot N:P

Figure 7

Correlations between the amount of tartrate in the rhizosheath and shoot nitrogen concentration ([N]), and shoot $\mathrm{N}$ to phosphorus mass ratio $(\mathrm{N}: \mathrm{P})$ of alfalfa grown in a loess soil in a greenhouse with different rates of added $\mathrm{P}$ and $\mathrm{N}$ in four forms. $\mathrm{OP}$ and 20P represent that $\mathrm{P}$ was added at 0 and $20 \mathrm{mg}$ $\mathrm{kg}-1$ as $\mathrm{KH} 2 \mathrm{PO} 4$, respectively 


\section{Supplementary Files}

This is a list of supplementary files associated with this preprint. Click to download.

- SupplementaryInformation.docx 